\title{
Geochemical and Sedimentation History of Neogene Lacustrine Sediments from the Valjevo-Mionica Basin (Serbia)
}

\author{
Aleksandra Šajnović ${ }^{1}$, Ksenija Stojanović1,2, \\ Vladimir Simić 3 and Branimir Jovančićević1,2 \\ ${ }^{1}$ University of Belgrade, Center of Chemistry, IChTM, Belgrade \\ ${ }^{2}$ University of Belgrade, Faculty of Chemistry, Belgrade \\ ${ }^{3}$ University of Belgrade, Faculty of Mining and Geology, Belgrade \\ Serbia
}

\section{Introduction}

Valjevo-Mionica Basin is one of the numerous lacustrine Neogene basins in Serbia. After Aleksinac Basin, according to the quality and amount of oil shale, it is one of the main deposits of this raw material in Serbia. The most important oil shale deposits in ValjevoMionica Basin are located in the central part of the basin ("Bela stena series", Sušeočka and Radobićka Bela Stena). The kerogen content in oil shales ranged from 8 - $16 \%$. The average oil yield of $6.3 \%$ is of economical value.

Total of 62 samples of Neogene lacustrine sedimentary rocks to the depth of $400 \mathrm{~m}$ were investigated in this study. The first objective of the study was to reconstruct geological history (evolution) of the sediments i.e. to determine the palaeoconditions in depositional environment during its formation. For this purpose numerous geochemical methods and approaches were used. The second objective of the study was to determine the origin, type, maturity and liquid hydrocarbon potential of organic matter (OM). Aimed at detailed estimation of the oil shale $\mathrm{OM}$ potential, and prediction of the conditions necessary to become active oil generating source rock, pyrolytic experiments were performed on the bitumen-free sample. Bearing in mind that some metal ions (e.g. $\mathrm{Al}(\mathrm{III})$-ion in clay minerals) (Jovančićević et al., 1993; Peters et al., 2005) have catalytic influence on most of the maturation processes, and that $\mathrm{Pt}(\mathrm{IV})$ - and $\mathrm{Ru}(\mathrm{III})$ - ions are often components of catalysts in many laboratory investigations and industrial procedures (Hu et al., 1994; Kawaguchi et al., 2005), the pyrolytic experiments of bitumen-free rock were performed also in the presence of simple inorganic compounds, $\mathrm{H}_{2}\left[\mathrm{PtCl}_{6}\right]$ and $\mathrm{RuCl}_{3}$, to investigate if their presence changes the yield and hydrocarbon composition of liquid pyrolysates.

\section{Geological characteristics of the investigated area}

Valjevo-Mionica Basin is situated in the western part of Serbia, covering an area of $350 \mathrm{~km}^{2}$. (Fig. 1). The Valjevo-Mionica Basin consists of lacustrine and marine sediments (Jovanović et al., 1994). The current investigations were focused on the lacustrine sediments from the 
drillhole Val-1 at depth interval of 0-400 m. Interval from 15 to $200 \mathrm{~m}$ depth is made of sediments of the Mionica series which covers an area of approximately $40 \mathrm{~km}^{2}$ (Dolić, 1984). Lithological characteristics of the Mionica series based on cores from the drillhole Val-1 down to depth of $200 \mathrm{~m}$ reflect transitions of oil shale, relatively rare thin beds or lenses of sandy siltstone and laminated shale, marlstone (dolomitic, sandy and clayey as well as tuffaceous), tuff, lenses enriched with searlesite and analcite and limestone with chert concretions. Another sedimentary interval underlying oil shale series is from 200 to $400 \mathrm{~m}$ depth. These sediments are represented by marlstone (dolomitic, sandy and clayey as well as tuffaceous), lenses of carbonates, siltstone, tuff and pyrite (Šajnović et al., 2008a).

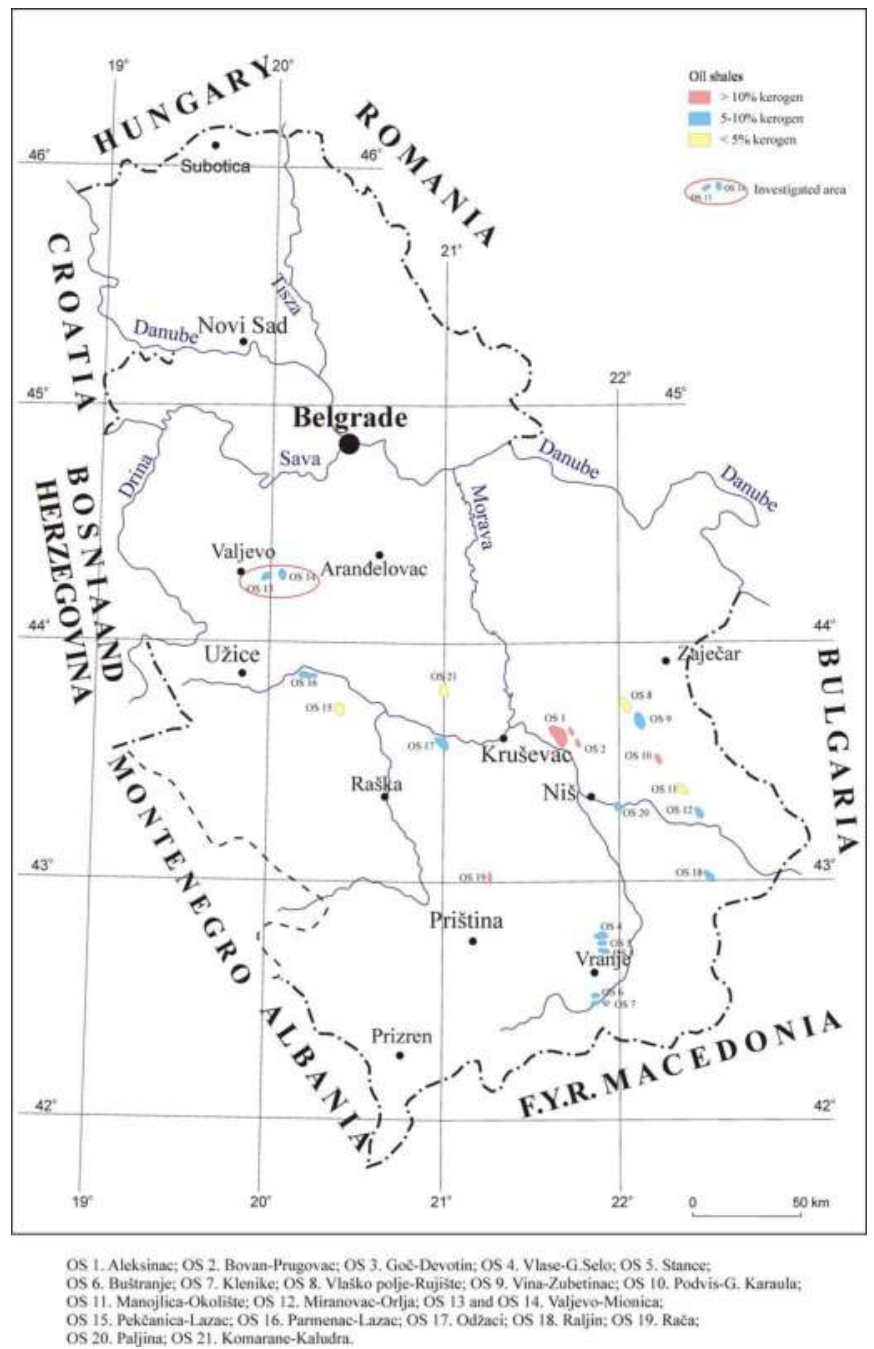

Fig. 1. The most important deposits of oil shales in Serbia with kerogen content and locaton of investigated area 


\section{Methods}

A total of 62 composite samples from drillhole Val-1 at depth to $400 \mathrm{~m}$ were prepared for investigation. From each plotted and cross-sectioned core of the drill hole, a quarter of core was taken for the preparation of composite samples.

The contents of $\mathrm{SiO}_{2}, \mathrm{Al}_{2} \mathrm{O}_{3}, \mathrm{Fe}_{2} \mathrm{O}_{3}, \mathrm{MgO}, \mathrm{CaO}, \mathrm{Na}_{2} \mathrm{O}, \mathrm{K}_{2} \mathrm{O}, \mathrm{TiO}_{2}$, as well as loss of ignition (LOI) were determined by X-ray fluorescence (XRF) spectrophotometry (Šajnović et al., 2008a, 2009). For X-ray fluorescence analysis, a sample powder was mixed with dilithium tetraborate $\left(\mathrm{Li}_{2} \mathrm{~B}_{4} \mathrm{O}_{7}\right.$, Spectromelt from Merck), pre-oxidized with $\mathrm{NH}_{4} \mathrm{NO}_{3}$, and fused to glass beads in Pt crucibles. The contents of $\mathrm{Sr}, \mathrm{Li}, \mathrm{B}$ and As were determined by ICP-OES spectrophotometry after standard digestion $\left(\mathrm{HNO}_{3}: \mathrm{HCl}=1: 3, \mathrm{v} / \mathrm{v}\right)$. These analytical methods were accredited in line with the ISO 9002 Standard. Reference samples were employed for calibration (CMLG, CS11, UXHG, IMV Gel for B content).

Qualitative composition of the mineral part was determined by X-ray powder diffraction method (Šajnović et al., 2008a, 2008b). The qualitative composition of the mineral part was determined by means of diffractometer Philips 1710 PW. The X-ray tube had following characteristics: $\mathrm{Cu} L F F, 40 \mathrm{kV}, 30 \mathrm{~mA}$. Surveying was performed under the following conditions: $\lambda=1.54060-1.54438 \mathrm{~nm}$, step width 0.020 and time $0.50 \mathrm{~s}$. The relative amount of the individual minerals was estimated qualitatively on the basis of the reflection of the most frequent peaks and comparison with the database (JCPDS-International Centre for Diffraction Data).

Elemental analysis was applied to determine the contents of carbon, sulphur and nitrogen. Organic carbon (Corg) was determined after removal of carbonates with diluted hydrochloric acid (1:3, v/v). The measurements performed using a Vario EL III, CHNOS Elemental Analyser, Elementar Analysensysteme $\mathrm{GmbH}$. Rock-Eval pyrolysis was performed on the Rock-Eval II apparatus following the method JUS ISO/IEC 17025. The analysis included $50 \mathrm{mg}$ of sample, and calibration $100 \mathrm{mg}$ of standard IFP 160000.

Soluble organic matter (bitumen) was extracted from sediments using the Soxhlet extraction method with an azeotrope mixture of dichloromethan and methanol for $42 \mathrm{~h}$. The saturated, aromatic, and NSO fractions (polar fraction, which contains nitrogen, sulfur, and oxygen compounds) were isolated from bitumen using column chromatography (Šajnović et al., 2008 b, 2009, 2010). Elemental sulfur from the saturated fraction was removed by the method suggested by Blumer (1957).

Pyrolyses were performed on soluble organic matter (bitumen) free sample, which contained kerogen with native mineral matrix. The pyrolytic experiments also were performed on bitumen-free sample in the presence of $\mathrm{H}_{2}\left[\mathrm{PtCl}_{6}\right]$ and $\mathrm{RuCl}_{3}$ under the same conditions. The organic carbon in bitumen-free sample to catalyst mass ratio was 10:1. Pyrolyses were performed in an autoclave under nitrogen for $4 \mathrm{~h}$ at temperature $400{ }^{\circ} \mathrm{C}$. Liquid pyrolysis products were extracted with hot chloroform. Gaseous products were not analyzed, although the production of gaseous products was indicated by the pressure change in the autoclave (Stojanović et al., 2009, 2010). Liquid pyrolysates were separated into saturated hydrocarbon, aromatic hydrocarbon, and NSO fractions using the same method as that applied for the fractionation of extracted bitumen.

Saturated and aromatic fractions isolated from the initial bitumen and pyrolysates were analyzed by gas chromatography-mass spectrometry (GC-MS). A gas chromatograph 
Shimadzu GC-17A gas chromatograph (DB-5MS+DG capillary column, $30 \mathrm{~m} \times 0.25 \mathrm{~mm}$, He carrier gas $1.5 \mathrm{~cm}^{3} / \mathrm{min}$, FID) coupled to a Shimadzu QP5050A mass selective detector (70 $\mathrm{eV}$ ) was used. The column was heated from 80 to $290^{\circ} \mathrm{C}$, at a rate of $2{ }^{\circ} \mathrm{C} / \mathrm{min}$, and the final temperature of $290{ }^{\circ} \mathrm{C}$ was maintained for an additional $25 \mathrm{~min}$. Saturated fractions were analyzed for $n$-alkanes and isoprenoids from the $m / z 71$, steranes from the $m / z 217$, and terpanes from the $m / z \quad 191$ ion fragmentograms. Methyl-, dimethyl-, and trimethylnaphthalenes in the aromatic fractions were identified from the $m / z 142,156$, and 170 ion fragmentograms, whereas phenanthrene, methyl-, and dimethylphenanthrene isomers were analyzed from the $\mathrm{m} / \mathrm{z} 178,192$, and 206 ion fragmentograms. The individual peaks were identified by comparison with the literature data (Peters et al., 2005; Radke, 1987) and on the basis of the total mass spectra (libraries: NIST 107, NIST 121, PMW_tox3 and Publib/Wiley 229).

\section{Results and discussion}

\subsection{Mineral composition}

Mineral composition of sediments is characterized by predomination of dolomite and calcite, which were found in all samples. Contents of quartz, illite and chlorite were changeable. All samples from depth interval 15 to $200 \mathrm{~m}$, which contain oil shale, are characterized by the presence of analcite (Fig. 2). Analcite is mainly linked with marine or lacustrine sediments which are formed in conditions of increased salinity and alkalinity (Remy \& Ferrel, 1989). Feldspars, smectite and amphiboles were indicated by X-ray analyses, but they should be confirmed by detailed studies. According to certain specificities of the mineral composition, two important depth intervals were defined in the drillhole Val1. The first interval is from 15 to $75 \mathrm{~m}$ depth. It is characterized by presence of searlesite (Fig. 2a), which is genetically linked to volcanogenic material. Another geochemically specific interval is at the depth of $360-400 \mathrm{~m}$, and is characterised by interstratified clay minerals most probably of illite-smectite composition (lithium-bearing Mg-smectite) (Fig. 2b).
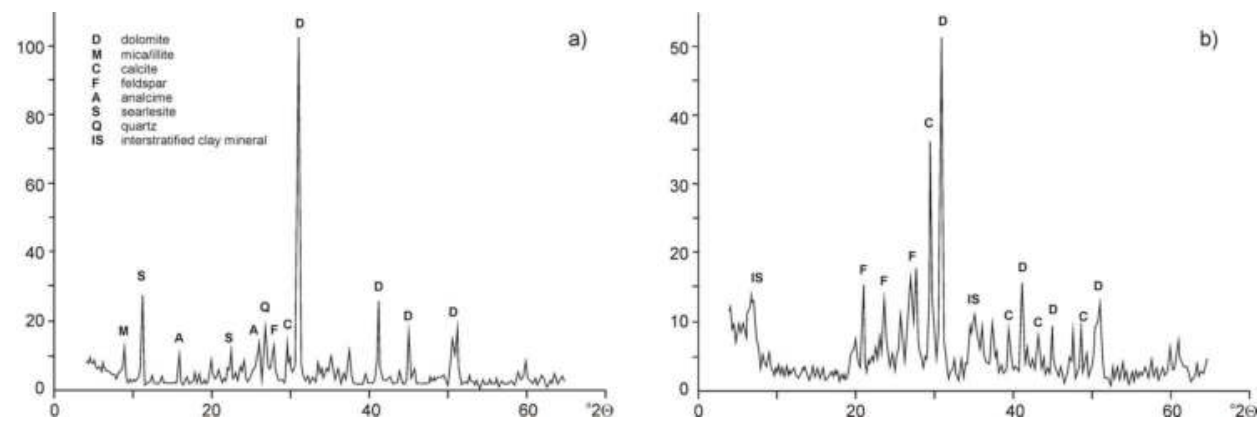

Fig. 2. Characteristic X-ray diffractograms of sediments from depth interval 15-75 m (a) and depth interval $360-400 \mathrm{~m}(\mathrm{~b})$

\subsection{Geochemical parameters}

Conditions which existed in the sedimentation environment, like water level, salinity, and climatic conditions, are reflected in the values of geochemical parameters ( $\mathrm{Ng} \& \mathrm{King}, 2004)$. 
For this purpose numerous group and specific geochemical parameters (Šajnović et al., 2008a, 2008b, 2009, 2010) were determined based on detailed investigation of inorganic part of sediments and its organic matter (kerogen and bitumen) (Tables 1 and 2). The differences in mineral composition and geochemical characteristics of the sediments indicate that the conditions in the sedimentation area changed over the time. That allowed defining four different depth intervals (Table 1).

\begin{tabular}{|c|c|c|c|c|c|c|c|c|c|c|c|c|c|c|c|c|c|}
\hline \multirow[b]{3}{*}{ Parameter } & \multicolumn{17}{|c|}{ Depth interval (m) } \\
\hline & \multicolumn{4}{|c|}{$15-75$} & \multicolumn{5}{|c|}{$75-200$} & \multicolumn{4}{|c|}{$200-360$} & \multicolumn{4}{|c|}{$360-400$} \\
\hline & 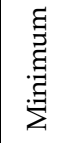 & 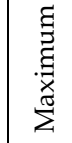 & 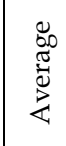 & के & 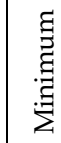 & & 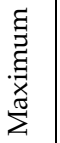 & 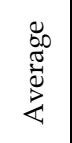 & के & $\begin{array}{l}\text { 嵩 } \\
\text { 弯 }\end{array}$ & 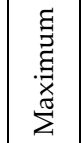 & 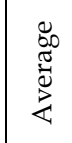 & कि & 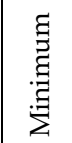 & 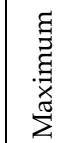 & 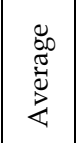 & के \\
\hline $\mathrm{Si}$ & 25.80 & 34.30 & 29.36 & 2.12 & .0 & & 6.80 & 32.70 & 2.28 & 23.60 & 43.80 & 36.0 & 6.67 & 28.20 & 33.00 & 29.68 & 2.2 \\
\hline $\mathrm{Al}_{2}$ & 7.35 & .70 & 29 & 1.19 & .7 & & 3.60 & 11.52 & 1.18 & 6.58 & 15.40 & 11.93 & 2.78 & 7.07 & 8.17 & 7.52 & \\
\hline & 3.10 & 4.93 & 3.84 & 0.41 & 3.97 & & 5.01 & 4.51 & \begin{tabular}{|l|}
0.31 \\
\end{tabular} & 2.64 & \begin{tabular}{|l|}
7.39 \\
\end{tabular} & 5.19 & 1.43 & 3.02 & 3.56 & \begin{tabular}{|l|}
3.19 \\
\end{tabular} & \\
\hline & 4.56 & 9.95 & 7.79 & 1.53 & 4.26 & & 7.65 & 6.12 & \begin{tabular}{|l|}
0.96 \\
\end{tabular} & 2.83 & 6.84 & 4.34 & 1.03 & 9.88 & 10.90 & 10.25 & \\
\hline & 9.78 & 19.40 & 14.19 & 2.33 & 10.7 & & 7.90 & 14.81 & 2.24 & 7.66 & 30.20 & 15.34 & 6.66 & 15.40 & 19.20 & 17.83 & 1. \\
\hline & 0.86 & 4.23 & 3.07 & 0.91 & 43 & & 2.38 & 2.00 & 0.26 & \begin{tabular}{|l|}
0.98 \\
\end{tabular} & \begin{tabular}{|l|}
1.77 \\
\end{tabular} & 1.49 & 0.22 & \begin{tabular}{|l|l}
1.04 \\
\end{tabular} & 1.35 & 1.20 & 0. \\
\hline & 2.25 & 3.23 & 2.64 & 0.29 & .5 & & 3.45 & 3.00 & \begin{tabular}{|l|}
0.28 \\
\end{tabular} & 1.56 & 3.21 & 2.65 & 0.51 & 2.92 & 4.32 & \begin{tabular}{|l|}
3.49 \\
\end{tabular} & 0. \\
\hline & 0.26 & 0.42 & 0.32 & 0.04 & 0.3 & & 0.48 & 0.39 & \begin{tabular}{|l|}
0.04 \\
\end{tabular} & \begin{tabular}{|l|}
0.24 \\
\end{tabular} & \begin{tabular}{|l|l|}
0.64 \\
\end{tabular} & 0.46 & 0.13 & 0.26 & 0.28 & \begin{tabular}{|l|}
0.27 \\
\end{tabular} & 0.0 \\
\hline LOI & 21.90 & 29.80 & 26.45 & 1.89 & 20.4 & & 5.90 & 22.96 & \begin{tabular}{|l|}
1.68 \\
\end{tabular} & 13.80 & 28.10 & 19.92 & 4.59 & 21.70 & 25.30 & 24.08 & 1.64 \\
\hline As (p & 20 & 93 & 57 & 18.9 & 20 & & 54 & 29 & \begin{tabular}{|l|}
9.60 \\
\end{tabular} & 20 & 31 & 26 & 3.41 & 10 & 37 & 11 & 14.00 \\
\hline & 120 & 390 & 252 & 64.68 & 140 & & 560 & 269 & 106 & 130 & 370 & 180 & 53 & 890 & 1100 & 1000 & 116 \\
\hline Sr ( & 520 & 1600 & 1100 & 276 & 630 & & 1100 & 881 & 139 & 390 & 11000 & 1700 & 2646 & 2700 & 7700 & 4025 & 2451 \\
\hline & 120 & 7780 & 3811 & 2363 & 50 & & 440 & 194 & 134 & 110 & 230 & 175 & 41 & 230 & 770 & 495 & 278 \\
\hline & 39 & 4.75 & 3.32 & 0.86 & 0.68 & & 3.63 & 2.42 & 0.82 & 0.51 & 1.96 & 1.10 & 0.41 & 0.47 & 1.51 & 1.07 & 0.4 \\
\hline & 3.12 & 10.86 & 7.17 & 2.20 & 1.42 & & 5.88 & 3.75 & 1.18 & 0.32 & 4.36 & 1.94 & 1.24 & 1.78 & 3.82 & 2.92 & \\
\hline & 16.66 & 71.40 & 47.77 & 13.1 & 7.02 & & 6.26 & 29.18 & 10.70 & 0.96 & 21.12 & 8.14 & 6.24 & 3.66 & 20.04 & 12.98 & 6.96 \\
\hline & 582 & 1044 & 695 & 98 & 544 & & 745 & 661 & 55 & 126 & 603 & 359 & 151 & 369 & 672 & 542 & 131 \\
\hline $\max \left({ }^{\circ} \mathrm{C}\right)$ & 428 & 434 & 430 & 1.70 & 428 & & 436 & 433 & \begin{tabular}{|l|}
2.04 \\
\end{tabular} & \begin{tabular}{|l|}
419 \\
\end{tabular} & 433 & 425 & 3.93 & 416 & 432 & 425 & 6.68 \\
\hline
\end{tabular}

LOI - loss of ignition; Corg - organic carbon content from elemental analysis; S1 - free hydrocarbons in $\mathrm{mgHC} / \mathrm{g}$ rock; $\mathrm{S} 2-$ pyrolysate hydrocarbons in $\mathrm{mgHC} / \mathrm{g}$ rock; $\mathrm{HI}-$ hydrogen index $=\mathrm{S} 2 \times 100 / \mathrm{TOC}$ in $\mathrm{mgHC} / \mathrm{gTOC}$; HC - hydrocarbons; TOC - total organic carbon; Tmax - temperature corresponding to S2 peak maximum; SD - standard deviation

Table 1. Characteristical depth intervals and values of geochemical parameters

\subsubsection{Depth interval 15-75 m}

Relatively low values of the main inorganic geochemical parameters like $\mathrm{SiO}_{2}, \mathrm{Al}_{2} \mathrm{O}_{3}, \mathrm{Fe}_{2} \mathrm{O}_{3}$, $\mathrm{TiO}_{2}$ and $\mathrm{CaO}$ in this interval indicate that the share of alumosilicate and carbonate fraction was low (Table 1). Change of contents of $\mathrm{K}_{2} \mathrm{O}$ is similar to behaviour of $\mathrm{SiO}_{2}$ and $\mathrm{Al}_{2} \mathrm{O}_{3}$, what indicates the connection between $\mathrm{K}_{2} \mathrm{O}$ and alumosilicates. This is confirmed by minerological analysis, that is presence of illite and rarely K-feldspar (Fig. 2a). Presence of potassium and terrigenic component is explained by the fact that potassium is mainly accumulated in clays by weathering and leaching processes as a result of syn- and postdepositional adsorption and ion exchange in salty or salted waters (Grim, 1968). Total iron $\left(\mathrm{Fe}_{2} \mathrm{O}_{3}\right)$ may be found in crystal lattice of clay minerals, especially illite and chlorite. The 
other possible connection is with colloid oxides and hydroxides of manganese $(\mathrm{MnO})$ and titanium $\left(\mathrm{TiO}_{2}\right)$, which are, apart from clays, important constituents of recent sediments. The mentioned oxides and hydroxides may be found alone or in form of film on clay or other minerals. Contents of $\mathrm{Li}$ in depth interval $15-75 \mathrm{~m}$ is relatively low, whereas Sr content is relatively high and in positive correlation with LOI, indicating that it is connected with carbonate fraction (Table 1).

\begin{tabular}{|c|c|c|c|c|c|c|c|c|c|c|c|c|c|c|c|c|}
\hline \multirow[b]{3}{*}{ Parameter } & \multicolumn{16}{|c|}{ Depth interval (m) } \\
\hline & \multicolumn{4}{|c|}{$15-75$} & \multicolumn{4}{|c|}{$75-200$} & \multicolumn{4}{|c|}{$200-360$} & \multicolumn{4}{|c|}{$360-400$} \\
\hline & 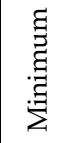 & 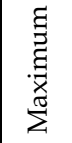 & 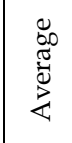 & कि & 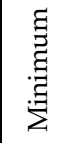 & 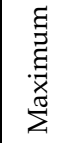 & 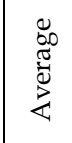 & के & 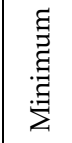 & 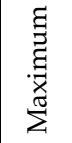 & 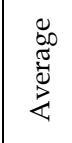 & के & 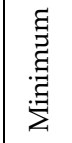 & 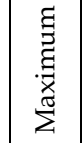 & 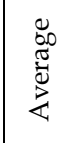 & के \\
\hline CPI & 1.38 & 2.29 & 1.90 & 0.26 & 1.26 & 3.06 & 2.04 & \begin{tabular}{|l|}
0.52 \\
\end{tabular} & 0.84 & 2.20 & 1.61 & 0.32 & 1.22 & 1.58 & 1.43 & 0.16 \\
\hline$n-\mathrm{C}_{17} / n-\mathrm{C}_{27}$ & 0.54 & 5.37 & 2.58 & 1.38 & 0.24 & 5.90 & 1.94 & 1.51 & 0.77 & 9.18 & 2.39 & 2.09 & 1.23 & 3.19 & 1.83 & 0.92 \\
\hline $\mathrm{Pr} / \mathrm{Ph}$ & 0.05 & 1.12 & $0.51^{*}$ & 0.33 & 0.02 & 0.53 & 0.14 & 0.12 & 0.06 & 0.67 & 0.31 & 0.18 & 0.45 & 0.85 & 0.63 & 0.18 \\
\hline $\mathrm{Pr} / n-\mathrm{C}_{17}$ & 0.06 & \begin{tabular}{|l|}
1.01 \\
\end{tabular} & 0.51 & 0.33 & 0.05 & \begin{tabular}{|l|}
0.98 \\
\end{tabular} & 0.22 & 0.19 & 0.15 & 1.10 & 0.49 & 0.28 & 1.09 & 2.29 & 1.50 & 0.56 \\
\hline $\mathrm{Ph} / n$ - & 0.91 & 7.89 & 2.20 & 1.55 & 0.52 & 25.0 & 5.50 & 5.25 & 0.62 & \begin{tabular}{|l|}
8.76 \\
\end{tabular} & 4.31 & 2.49 & 3.01 & 13.29 & 6.24 & 4.75 \\
\hline $\mathrm{Sq} / r$ & 0.75 & 3.53 & 2.17 & 0.89 & 0.24 & 4.14 & 0.97 & 0.87 & 0.14 & 1.86 & 0.41 & 0.42 & 0.44 & 0.99 & 0.67 & 0.26 \\
\hline$i-25 / n-\mathrm{C}_{22}$ & 00 & 0.22 & 0.11 & 0.07 & \begin{tabular}{|l|}
0.04 \\
\end{tabular} & \begin{tabular}{|l|}
0.27 \\
\end{tabular} & 0.16 & 0.07 & 0.08 & 0.70 & 0.27 & 0.19 & 0.37 & 0.99 & 0.72 & 0.27 \\
\hline$\%($ & 33.23 & 47.96 & 41.52 & 4.14 & 36.84 & 57.63 & 44.01 & 5.07 & 27.51 & 44.43 & 34.07 & 4.35 & 39.34 & 42.98 & 41.68 & 1.68 \\
\hline 0 & .06 & 45.21 & 31.18 & 6.99 & 14.58 & 38.56 & 26.99 & 5.64 & 19.78 & 32.18 & 23.96 & 4.27 & 20.32 & 23.33 & 21.30 & 1.37 \\
\hline$\% \mathrm{C}_{29}$ & 19.14 & 37.04 & 27.30 & 5.83 & 18.22 & 40.38 & 29.00 & 5.89 & 33.65 & 51.13 & 41.97 & 5.06 & 36.31 & 38.11 & 37.02 & 0.87 \\
\hline \begin{tabular}{|c|}
$\mathrm{C}_{27} \alpha a \alpha(\mathrm{R}) /$ \\
$\mathrm{C}_{29}{ }_{29 \alpha a(\mathrm{R})}$
\end{tabular} & 1.02 & 2.19 & 1.59 & 0.37 & 1.05 & 3.16 & 1.61 & 0.53 & 0.54 & 1.24 & 0.83 & 0.19 & 1.05 & 1.18 & 1.13 & 0.06 \\
\hline $\begin{array}{c}\mathrm{G} \times 100 / \\
\mathrm{C}_{30} \mathrm{H}\end{array}$ & 11.11 & 57.14 & 30.86 & 13.09 & 14.71 & 56.25 & 30.81 & 10.90 & 14.10 & 84.31 & 45.93 & 19.20 & 6.67 & 37.50 & 17.69 & 14.51 \\
\hline${ }_{30} \mathrm{M} / \mathrm{C}_{30} \mathrm{H}$ & 1.47 & 10.64 & 7.05 & 2.35 & \begin{tabular}{|l|}
1.49 \\
\end{tabular} & 11.92 & 4.56 & 2.70 & 0.49 & \begin{tabular}{|l|}
1.55 \\
\end{tabular} & 0.86 & 0.33 & 0.73 & 1.30 & 1.08 & 0.2 \\
\hline
\end{tabular}

*average value does not real, since it is increased due to relative high values of $\mathrm{Pr} / \mathrm{Ph}$ ratio for samples at depths to $30 \mathrm{~m}$; CPI - carbon preference index determined for full amplitude of $n$-alkanes (Bray \& Evans, 1961); $\mathrm{Pr}$ - pristane; $\mathrm{Ph}$ - phytane; $\mathrm{Sq}$ - squalane; $i-25$ - $\mathrm{C}_{25}$ regular isoprenoid; $\% \mathrm{C}_{27}, \mathrm{C}_{28}, \mathrm{C}_{29}$ regular sterane relative contents calculated from the peak areas of $\mathrm{C}_{27}-\mathrm{C}_{29} 5 \mathrm{a}(\mathrm{H}) 14 \mathrm{a}(\mathrm{H}) 17 \mathrm{a}(\mathrm{H}) 20(\mathrm{R})$ isomers; $C_{27} \alpha \alpha a(R)-5 a(H) 14 a(H) 17 a(H) 20(R)$-sterane; $C_{29} \alpha a \alpha(R)-5 a(H) 14 a(H) 17 a(H) 20(R)$-sterane; $\mathrm{G}$ - gammacerane; $\mathrm{C}_{30} \mathrm{H}$ - 17 $\alpha(\mathrm{H}) 21 \beta(\mathrm{H})$-hopane; $\mathrm{C}_{30} \mathrm{M}$ - 17 $\beta(\mathrm{H}) 21 \alpha(\mathrm{H})$-moretane; SD - standard deviation

Table 2. Characteristical depth intervals and values of specific organic geochemical parameters

What makes this depth interval specific compared to the others is very high contents of $\mathrm{Na}_{2} \mathrm{O}$ in main elements, $\mathrm{B}$ and As in the microelements (Table 1). It is well known that in comparison to other environments, Neogene lacustrine sediments are enriched in B and As (Alonso, 1999; Yudovich \& Ketris, 2005). The contents of boron and arsenic in lacustrine sediments depend on: active volcanism, closed basin, arid to semi-arid climate, tectonic activity, $\mathrm{pH}$, salinity, redox potential, temperature, type of the surrounding minerals in the depositional environment (Helvaci \& Alonso, 2000; Kazanci et al., 2006; Valero-Garcés et al., 1999). The highest levels of boron in detrial sedimentary rocks are usually associated with argillaceous facies and are related to the amount and type of the mineral presents (Aggarwal 
et al., 2000). Hydrated borate minerals accumulate as evaporate deposits in an arid, closed basin environment (Alonso, 1999; Floyd et al., 1998). Also, in arid areas, boron is likely to be co-precipitated with $\mathrm{Mg}$ and $\mathrm{Ca}$ hydroxides as coatings on the particles of the sediments, and it may also occur as Na-metaborate. Mineralogical analyses showed that dolomite and calcite were predominant in the investigated sediments and were found in all the examined samples (Fig. 2). Conditions of sedimentation, characterised by high salinity and $\mathrm{pH}$ and the presence of aluminosilicates and calcium and magnesium minerals, were suitable for boron accumulation. Therefore, sediments from this depth interval contained an order of magnitude higher amount of boron than sediments from other depth intervals (Table 1). Also, these sediments are characterised with increased contents of $\mathrm{Na}_{2} \mathrm{O}$ and As compared to the other samples (Table 1) and the presence of the mineral searlesite (Fig. 2a), which is formed through the contact of sodium-rich alkaline saline waters with volcanic glass, which was the source of boron (Peng et al., 1998).

This interval is characterised by the highest average values of all bulk organic geochemical parameters (Corg, S1, S2, HI), with the exception of maturity parameter, temperature of maximum generation, Tmax (Table 1). Samples from depths 15-75 m contained relatively high amount of organic matter (Corg). This is also holds for the content of soluble OM expressed as $\mathrm{S} 1$ and for the content of hydrocarbons formed by pyrolysis, expressed through S2 (Table 1.) Relatively high values of hydrogen index (Table 1) show that OM of the samples consists predominantly of Type I and/or I/II kerogen, with a good potential for liquid hydrocarbons generation. The average value of Tmax indicates low maturity degree of OM, which is expected since at these depths OM was not exposed to more significant thermal stress.

The $n$-alkane distribution is characterised by domination of $n-C_{17}$ and relatively low proportion of longer chain $n$-alkane homologues (Fig. 3a, Table 2). In the immature samples, $n-\mathrm{C}_{17}$ origin is associated to cyanobacteria and/or algae. Reducing conditions in saline lacustrine environments are caused by the high salinity of water and linked density stratification impeding vertical mixing of strata water body. This results in extremely anoxic conditions in the depositional environment (Peters et al., 1996), documented by very low $\mathrm{Pr} / \mathrm{Ph}$ ratio of 0.05 (Table 2, see *).

In relatively immature sediments, pristane and phytane are presumed to originate from phytol, being a side chain in chlorophyll $a$ structure of phototrophic organisms. However, there are other sources of phytane, like membrane lipids from methanogenic or halophilic archaea (Anderson et al., 1977; Volkman \& Maxwell, 1988). Squalane is present in all of these sediments in relatively high quantities (Fig. 3a; Table 2). Squalane is presumed to originate from Halophihlic archaea (Grice et al., 1998), and is interpreted as indicator for hypersaline depositional environment. Very high quantities of phytane, $C_{25}$ (i-25) and $C_{30}$ (squalane) regular isoprenoids were found in a numerous saline lakes of non-marine origin in China (Wang \& Fu, 1997). In this contest, the $\mathrm{Sq} / n-\mathrm{C}_{26}$ ratio is often calculated, averaging a value of 2 , indicating environments with very high salt content. Sediments from depth interval 15$75 \mathrm{~m}$ are characterized with high phytane and squalane contents $\left(\mathrm{Sq} / n-\mathrm{C}_{26}>1\right.$, and in some samples even over 3), whereas $i-25$ was not identified, or was present in small quantity (Fig. 3a). This result shows that in the current study area such extremely saline anoxic conditions did not suitable for precursors of $i-25$. 

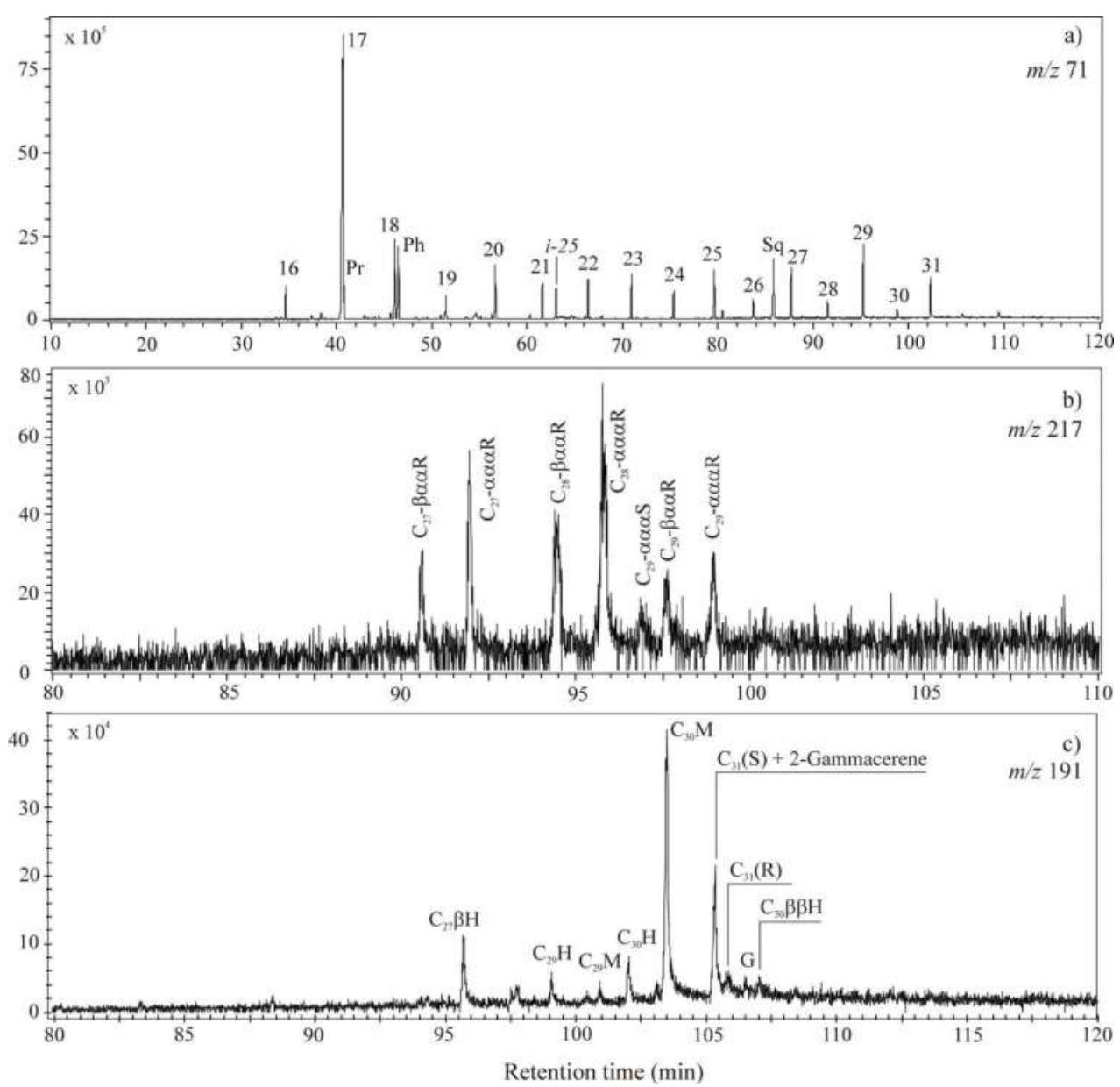

$n$-alkanes are labelled according to their carbon number; $\mathrm{Pr}$ - pristane; $\mathrm{Ph}$ - phytane; $i-25-\mathrm{C}_{25}$ regular isoprenoid; $\mathrm{Sq}$ - squalane; $\beta a \alpha$ and aqa designate $5 \beta(\mathrm{H}) 14 \alpha(\mathrm{H}) 17 \mathrm{\alpha}(\mathrm{H})$ and $5 \mathrm{\alpha}(\mathrm{H}) 14 \alpha(\mathrm{H}) 17 \mathrm{a}(\mathrm{H})$ configurations, $(\mathrm{R})$ and $(\mathrm{S})$ designate configuration at $\mathrm{C}_{20}$ in steranes; $\mathrm{C}_{27} \mathrm{BH}-\mathrm{C}_{27} 17 \beta(\mathrm{H})-22,29,30-$ trisnorhopane; $\mathrm{C}_{30} \beta \beta \mathrm{H}-\mathrm{C}_{30} 17 \beta(\mathrm{H}) 21 \beta(\mathrm{H})$-hopane; for other peak assignments, see legend, Fig. 7

Fig. 3. GC-MS ion fragmentogram of $n$-alkanes and isoprenoids, $m / z 71$ (a), steranes, $m / z 217$ (b) and terpanes, $m / z 191$ (c) representative for sediments from depth interval 15-75 m

$\mathrm{C}_{27}$ steranes in saturated lipid fraction of sediments in this depth interval accounts for over $40 \%$, and in some cases reaches even $50 \%$, whereas $\mathrm{C}_{28}$ sterane content accounts for approximately $30 \%$ in total distribution of $\mathrm{C}_{27}-\mathrm{C}_{29}$ regular sterane homologues (Fig. 3b; Table 2). Considering that distribution of regular steranes might serve even in classification of sediments or basins compared to the degree of salinity (Wang \& Fu, 1997), the mentioned 
data, apart from the high contents of isoprenoids squalane and phytane, represent another confirmation of hypersaline conditions of depositional environment in depth interval 15-75 $\mathrm{m}$. The distribution of $14 \alpha(\mathrm{H}) 17 \alpha(\mathrm{H}) 20(\mathrm{R}) \mathrm{C}_{27}-\mathrm{C}_{29}$ regular steranes is often used in the evaluation of the OM type (Peters et al., 2005; Volkman, 2003). Based on high contents of $C_{27}$ and $\mathrm{C}_{28}$ steranes, distributions of $n$-alkanes dominated by $\mathrm{C}_{17}$ and high $\mathrm{HI}$ values (Tables 1 and 2) it might be concluded that the dominant source of OM during formation of sediments in this depth interval was from algal origin.

Concerning the distribution of terpane biomarkers, compounds with biological $\beta \beta$ configuration and $\beta a$-moretanes are predominant in investigated samples representing immature microbial biomass (Fig. 3c). This agrees with the low level of thermal maturity. Gammacerane, which is most often considered as indicator of water column stratification and environments with high salinity (Sinninghe Damsté et al., 1995), is present in relatively small quantities (Fig. 3c). This confirms to the fact that extremely saline conditions are not suitable for its precursors e.g. protozoa Tetrahymena (Brassell et al., 1988; Šajnović et al., 2008b).

\subsubsection{Depth interval 75-200 m}

Contents of $\mathrm{SiO}_{2}, \mathrm{Al}_{2} \mathrm{O}_{3}, \mathrm{Fe}_{2} \mathrm{O}_{3}$ and $\mathrm{TiO}_{2}$ are higher, comparing to sediments from 15 to 75 $\mathrm{m}$, whereas the contents of $\mathrm{MgO}, \mathrm{Sr}$ and $\mathrm{LOI}$ are lower. Contents of $\mathrm{Al}_{2} \mathrm{O}_{3}$ and $\mathrm{TiO}_{2}$ are the measure of clastic share of material (terrigenic origin), or erosion activity. In general, it may be said that in depth interval $75-200 \mathrm{~m}$, due to increased erosion activity, alumosilicate contents grows, and carbonate content falls. The greatest and most dramatic change was noticed in the reduction of the boron content (Table 1), what is mineralogically followed by absence of searlesite. In these sediments, lower contents of $\mathrm{Na}_{2} \mathrm{O}$ and As were observed, although these changes are not that prominent as in content of boron (Table 1).

Sediments from this depth interval are characterised with lower values of all bulk organic geochemical parameters than in previous interval, especially those connected with the quantity of organic matter (Table 1). Lower HI values indicate that $\mathrm{OM}$ is composed of mixed terrestrial-algal precursor biomass (kerogen types II and mixture I/II; Table 1). The maturation degree of organic matter of the sediments is low.

$n$-Alkane distribution of the saturated fraction is characterized by relatively high proportions of $n-C_{17}$, and $n-C_{27}, n-C_{29}, n-C_{31}$ long-chain odd $n$-alkanes (Fig. $4 \mathrm{a}$ ). Decreasing of the $n-\mathrm{C}_{17} / n-\mathrm{C}_{27}$ ratio indicates higher contribution of terrestrial precursor biomass (Table 2). Low value Pr/Ph ratio, in some cases of 0.07 (Table 2) suggests extremely anoxic conditions in the depositional environment (Peters et al., 1996). In addition, sediments from 75 to $200 \mathrm{~m}$ are characterized with low contents of $i-25$ and squalane (Fig. 4a; Table 2).

Sterane distribution with domination of $\mathrm{C}_{27}$ and $\mathrm{C}_{29}$ in similar proportions confirms mixed terrestrial algal precursor biomass, consistent with $\mathrm{HI}$ value and $n$-alkane distribution (Fig. $4 \mathrm{~b}$; Table 1). In distribution of terpane biomarkers, compounds with biological $\beta \beta$ configuration and $\beta a$-moretanes are predominant, whereas gammacerane is present in relatively low quantity (Fig. 4c). 


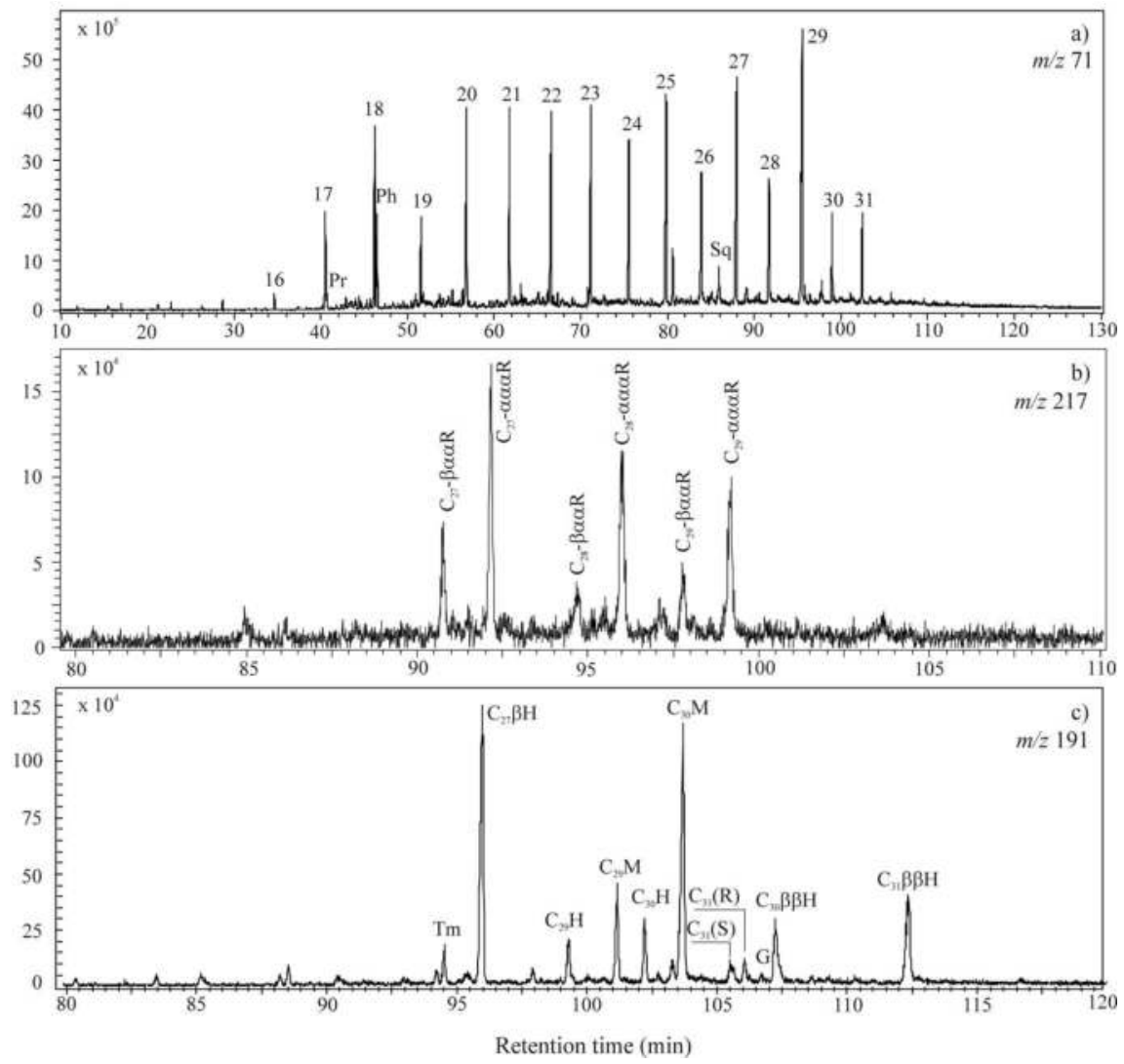

$\mathrm{C}_{31} \beta \beta \mathrm{H}-\mathrm{C}_{31} 17 \beta(\mathrm{H}) 21 \beta(\mathrm{H})$-hopane; for other peak assignments, see legends, Figs. 3 and 7

Fig. 4. GC-MS ion fragmentogram of $n$-alkanes and isoprenoids, $m / z 71$ (a), steranes, $m / z 217$ (b) and terpanes, $m / z 191$ (c) representative for sediments from depth interval 75-200 m

\subsubsection{Depth interval 200-360 m}

Contents of $\mathrm{SiO}_{2}, \mathrm{Al}_{2} \mathrm{O}_{3}, \mathrm{Fe}_{2} \mathrm{O}_{3}$ and $\mathrm{TiO}_{2}$ have the highest values; whereas the parameters connected with carbonate fraction ( $\mathrm{MgO}$ and LOI) have the lowest values in sediments from this depth interval (Table 1). Obtained results indicate significant contribution of clastic material.

Sediments of this depth interval contain the least quantity of the organic matter in the whole vertical profile (Table 1). As values of both $\mathrm{HI}$ and parameter S2 are the lowest compared to the other intervals, it is obvious that the $\mathrm{OM}$ of these sediments is of the lowest quality, composed mainly from kerogen type III and II/III with a low potential for production of liquid hydrocarbons. These bulk data provide further indication that the terrestrial $\mathrm{OM}$ significantly contributed to samples from depth interval 200-360 m. 
This is confirmed by biomarker distributions, which are characterized by domination of longer chain odd $n$-alkane homologues $\left(\mathrm{C}_{27}, \mathrm{C}_{29}\right.$ and $\left.\mathrm{C}_{31}\right)$ and pronounced proportion of $\mathrm{C}_{29}$ regular sterane (Fig. 5a,b; Table 2). Moreover, the samples contain low content of squalane, whereas $i-25$ is absent (Fig. 5a; Table 2). All the mentioned changes in composition and quality of OM of sediments in depth interval 200-360 m are caused by expressed erosion activity which resulted in high contribution of clastic material. Relatively high values of gammacerane index (Table 2) could be explained by water stratification, which was most probably result of the temperature changes (Sinninghe Damsté et al., 1995).
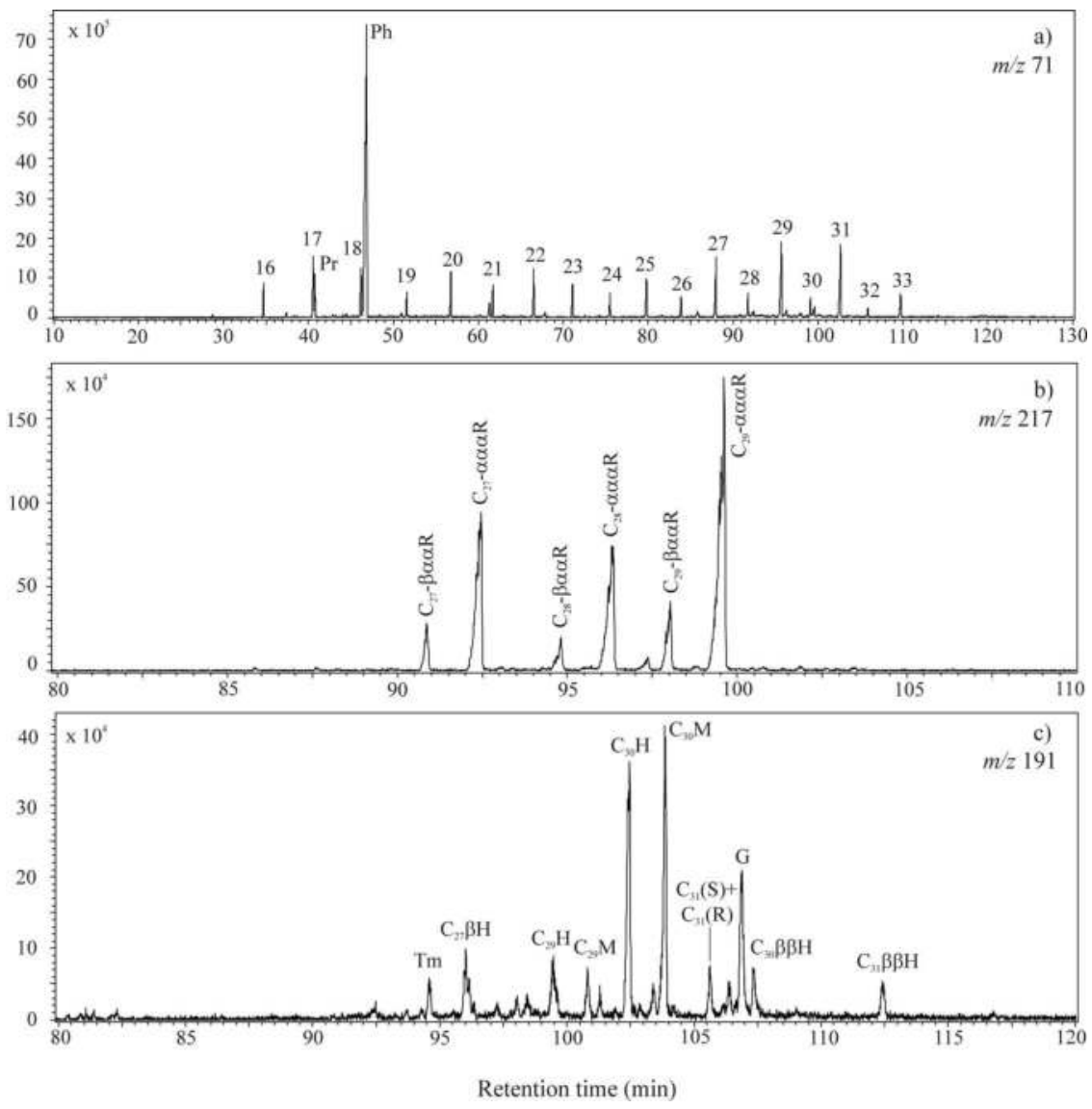

for peak assignments, see legends, Figs. 3, 4 and 7

Fig. 5. GC-MS ion fragmentogram of $n$-alkanes and isoprenoids, $m / z 71$ (a), steranes, $m / z 217$ (b) and terpanes, $m / z 191$ (c) representative for sediments from depth interval 200-360 m

\subsubsection{Depth interval 360-400 m}

The last drilled interval is characterised by high share of dolomite and calcite, but also with presence of already mentioned lithium clay minerals. The most important geochemical link 
in these sediments is related to the most likely presence of interstratified clay mineral type illite-saponite (lithium-bearing $\mathrm{Mg}$-smectite). This is indicated by high concentrations of $\mathrm{MgO}, \mathrm{K}_{2} \mathrm{O}$ and $\mathrm{Li}$ and their mutual geochemical correlation (Table 1), as well as X-ray analysis (Fig. 2b).

In this depth interval the quantity of the $\mathrm{OM}$ is higher in comparison with previous depth interval, as well as the content of boron. However, this increase is not as pronounced as in depth interval 15-75 m. Value of $\mathrm{HI}$ indicates that the OM is composed of different types of kerogen, and that it is on relatively low degree of maturation (Table 1).

The saturated lipid fraction of these samples is characterized by relatively high proportions of $n-C_{17}$, phytane and pristane (Fig. 6a). The maximum in the short-chain length range $\left(n-C_{17}\right)$ of the $n$-alkanes is higher than in the long-chain range, resulting in a $n-C_{17} / n-C_{27}$ ratio higher than 1 (Table 2). Odd homologues predominate among longer chain $n$-alkanes, and
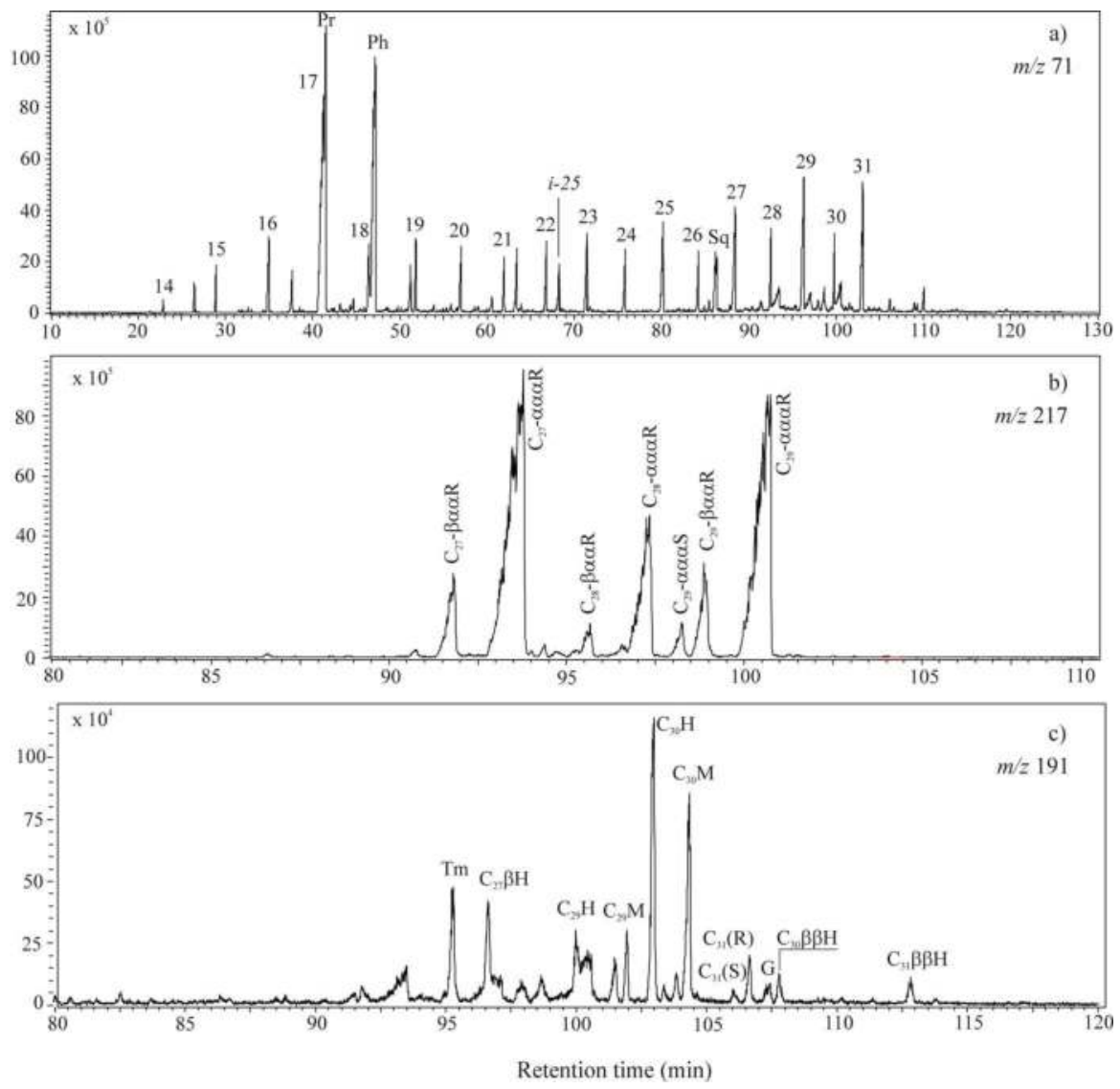

for peak assignments, see legends, Figs. 3, 4 and 7

Fig. 6. GC-MS ion fragmentogram of $n$-alkanes and isoprenoids, $m / z 71$ (a), steranes, $m / z 217$ (b) and terpanes, $m / z 191$ (c) representative for sediments from depth interval 360-400 m 
the maximum is at $n-C_{29}$ or $n-C_{31}$ (Fig. 6a). In sample 62 the relative proportion of pristane is highest among all investigated samples, causing the highest $\mathrm{Pr} / \mathrm{Ph}$ and $\mathrm{Pr} / n-\mathrm{C}_{17}$ ratios in the whole sample set. The isoprenoid alkane with 25 carbon atoms is present in relatively high quantity (Fig. 6a; Table 2). This indicates that the conditions with high $\mathrm{pH}$ values, i.e. alkaline environment are suitable for precursors of $\mathrm{C}_{25}$ isoprenoid. Literature data show that the most frequent precursors of this isoprenoid alkane are Archaea haloalkaliphiles, for which, apart from the alkaline environment, suitable is the environment with increased salinity (de Rosa et al., 1986). However, in case of sediments of depth from 360 to $400 \mathrm{~m}$, there is no indication of the increased salinity during their formation.

In some samples, $\mathrm{C}_{27}$-steranes accounted for approximately $40 \%$ (Table 2), and this observation was corroborated by high contents of $n-C_{17}$. The maturity of the organic matter of these samples being low, their high concentrations indicated a significant proportion of planktonic and cyanobacteric precursor organisms, which might have been favoured by increased alkalinity. Distributions of terpanes of the investigated samples are shown in figure $6 c$. The presence of thermodynamically less stable homologues with $\beta a$ (moretane) and $\beta \beta$ configurations confirms that the OM of the investigated sediments has a low level of maturity. Sediment samples are additionally characterized by the presence of gammacerane. However, the values of gammacerane index for samples from this depth interval are low (Table 2). This data lead to the assumption that high alkalinity conditions were not very favourable for survival of gammacerane precursors e.g. protozoa Tetrahymena (Šajnović et al., 2008b; ten Haven et al., 1988).

\subsection{Reconstruction of geological history based on geochemical and mineralogical parameters}

The relatively low degree of OM maturity in all investigated samples (diagenetic phase), provides an opportunity to relate values of organic geochemical parameters with OM origin and palaeoconditions in sedimentation environment. Interpretation of those parameters, combined with mineralogical data and content of macro- and microelements allows reconstruction of the geological history of sediments in the drillhole Val-1. Obtained results showed that the conditions, and consequently sources of $\mathrm{OM}$ in the sedimentary environment changed significantly, based on which different geochemical intervals (zones) were defined. In certain periods sediments were deposited under very specific conditions.

Depth interval $360-400 \mathrm{~m}$. Sediments from this interval were formed in alkaline conditions, with a variable bicarbonate to carbonate ratio. They are characterized by high content of magnesium, potassium and lithium, and also by presence of clay minerals of probably saponite, hectorite or interstratified illite-smectite types (Fig. 2b; Table 1), which needs further research. Results of elemental analysis and Rock-Eval pyrolysis indicate a moderately amount of immature OM (average organic carbon content, Corg, is $1.07 \%$; Table 1). Organic matter consists of kerogen types II and II/III. Biomarker distribution is characterized by domination of short chain over long chain $n$-alkanes, significant amount of phytane and regular isoprenoid $\mathrm{C}_{25}\left(i-\mathrm{C}_{25}\right)$, as well as by domination of $\mathrm{C}_{27}$-homologue in the distribution of $\mathrm{C}_{27}-\mathrm{C}_{29}$ regular steranes (Fig. 6a,b; Tables 1 and 2). These results indicate significant contribution of algal biomass to OM in sediments (Peters et al., 2005). Therefore, it may be supposed that alkaline conditions are suitable for algae, and for some specific organisms such as Archaea haloalkaliphile, which is the main precursor of $i-C_{25}$ (de Rosa et al., 1986). 
Depth interval 200-360 m. With time, environment is changed from calm to turbulent. Contents of magnesium, lithium and potassium in sediments decreased, whereas the contents of clastic material, $\mathrm{SiO}_{2}, \mathrm{Al}_{2} \mathrm{O}_{3}, \mathrm{Fe}_{2} \mathrm{O}_{3}$ and $\mathrm{TiO}_{2}$ are strongly increased, being the highest in the whole drillhole (Table 1). Mentioned changes resulted in decrease of $\mathrm{OM}$ content and quality (S1, S2 and HI; Table 1). Distribution of biomarkers, which is characterized by domination of odd homologues of long chain $n$-alkanes and high content of $\mathrm{C}_{29}$ sterane indicated significant contribution of terrestrial biomass to OM in sediments (Fig. $5 a, b)$. Sedimentary OM from this interval consists predominantly of Type III kerogen, with a low generative liquid hydrocarbons potential.

Depth interval 200-75 m. Significant changes in the sedimentary environment occurred when the formation of sediments from the depth of $200 \mathrm{~m}$, which belongs to Mionica series with oil shale, started. Those changes were primarily related to the increase in salinity, reflecting also in the increase of sodium content. The share of clastic sediments decreased, whereas the carbonate one increased (Table 1). Such conditions in sedimentary environment, followed by arid or semi-arid climate, allowed formation of analcite and better preservation of the OM, whose content increased in this depth interval (average, Corg, 2.42 $\%$; Table 1). Biomarker distribution, which is characterized by high contents of $n$-alkanes ( $n$ $\mathrm{C}_{17}, n-\mathrm{C}_{27}, n-\mathrm{C}_{29}, n-\mathrm{C}_{31}$ ) and phytane, uniform distribution of $\mathrm{C}_{27}-\mathrm{C}_{29}$ regular steranes and also by low abundance of squalane, $i-25$ and pristane, indicates that sedimentary $\mathrm{OM}$ originates from mixed terrestrial/algal biomass, deposited under slightly anoxic conditions (Fig. 4a,b). It contains kerogen types II and I/II.

Depth interval 75-15 m. Salinity continues to increase in the sedimentation environment. Sediments from this interval were formed under the conditions of high salinity. The presence of clay minerals and calcium and magnesium minerals allows the accumulation of boron. Sediments from this interval have the highest content of boron, sodium and arsenic in the whole drillhole Val-1 and are characterized by the presence of searlesite (Fig. 2a; Table 1). Searlesite was probably formed by reaction of saline waters rich in sodium with thin beds of volcanic tuff. Such calm environment with high salt concentration and intensive evaporation, allowed increased bioproductivity of algal biomass and preservation of the deposited OM, due to pronounced stratification of water column. All that resulted in high content of the OM in sediments from this interval (average Corg is $3.32 \%$; Table 1), which consists of kerogen types I and I/II with good generative liquid hydrocarbons potential. Biomarker distribution is characterized by predominance of short chain over long chain $n$-alkanes, significant amount of phytane and squalane, as well as by domination of $\mathrm{C}_{27}$-homologue in the distribution of $\mathrm{C}_{27}-\mathrm{C}_{29}$ regular steranes (Fig. 3a,b).

\subsection{Pyrolysis and catalyzed pyrolysis in the investigation of an oil shale potential}

The generative potential of an oil shale from the Valjevo-Mionica Basin was investigated using conventional pyrolysis and pyrolysis in the presence of $\mathrm{Pt}(\mathrm{IV})$ - and $\mathrm{Ru}(\mathrm{III})$-ions (Stojanović et al., 2010). Pyrolysis was performed on bitumen-free oil shale sample from the most interesting depth interval (15-75 m).

\subsubsection{Characteristics of organic matter in the oil shale sample}

Group organic geochemical parameters obtained by elemental analysis and Rock-Eval pyrolysis indicate the oil shale has significant generative potential with a total organic 
carbon content (Corg) of $3.40 \%$, a Hydrogen Index (HI) of $600 \mathrm{mgHC} / \mathrm{gTOC}$, and a Tmax of $428^{\circ} \mathrm{C}$. These values are consistent with the presence of immature to marginally mature, oil-prone organic matter composed primarily of kerogens type I or I/II. Soxhlet extraction of the shale with an azeotrope mixture of dichloromethan and methanol yielded $5054 \mathrm{ppm}$ of bitumen. The relatively high bitumen content in an immature sample may be explained by the presence of a significant amount of polar fraction (94.83\%), which is not readily expelled from the kerogen or did not incorporate into the kerogen matrix during late diagenesis (Stojanović et al., 2010; Šajnović et al., 2010).

The $n$-alkane distribution in bitumen extracted from the oil shale is characterised by pronounced $n-\mathrm{C}_{17}$ domination, typical for organic matter of predominantly algal origin (Fig. 3a). CPI value for full amplitude of $n$-alkane range of 3.38 indicates low maturity, which has also been confirmed on the basis of the values of group organic geochemical parameters (Tmax and group bitumen composition). $\mathrm{Pr} / \mathrm{Ph}$ ratio in bitumen extracted from the initial shale is 0.29 , which indicates reducing conditions during deposition of the organic matter that contributed to its preservation.

Sterane distribution of saturated fraction of the extracted shale bitumen is characterised by the predominance of homologues with unstable $\alpha a \alpha(R)$ - and $\beta a \alpha(R)$-configurations (Fig. $3 b)$, which again confirms a low maturity. Among them, $\mathrm{C}_{27}$ - and $\mathrm{C}_{28}$-steranes are in higher proportions, which is in agreement with predominantly algal origin of the organic matter. Steranes with $\alpha \beta \beta(R)-, \alpha \beta \beta(S)$-configuration and typical geoisomers, $\beta a$ - and $\alpha \beta$-diasteranes were not identified, and only $C_{29}$ sterane with aqa(S)- configuration is present in low amount (value of $\mathrm{C}_{29} \alpha a \alpha(S) / \mathrm{C}_{29} \alpha a \alpha(S+R)$ ratio $=0.20$ ).

Distribution of terpane biomarkers in bitumen isolated from the initial shale is characterised with domination of thermodynamically less stable $\beta a$ - and $\beta \beta$-isomers, the most abundant being $\mathrm{C}_{30} \beta \mathrm{a}$-moretane $\left(\mathrm{C}_{30} \mathrm{M} / \mathrm{C}_{30} \mathrm{H}\right.$ ratio $>5$; Fig. $\left.3 \mathrm{c}\right)$. Terpanes typical for extracts of more mature source rocks and crude oils, such as, Tm, Ts, $\mathrm{C}_{29} \mathrm{Ts}$ and series of 22(S)-homohopane isomers, were not identified with exception of $C_{31}(S)$, which as minor component that coelutes with 2-gammacerene. $\mathrm{C}_{29}$ and $\mathrm{C}_{30} \mathrm{\alpha} \beta$-Hopanes are present in small quantity, as well as thermodynamically less stable epimer of $\mathrm{C}_{31}$-homohopane with biological 22(R)configuration (Fig. 3c).

Components of aromatic fraction, methyl- dimethyl- and trimethylnaphthalenes, as well as methyl- and dimethylphenanthrenes typical for more mature source rock bitumens and oils, were not identified or are present in traces in the shale extract, with exception of phenanthrene. The observation is consistent with the low maturity of the organic matter since the main quantity of alkylaromatics is generated during catagenesis.

\subsubsection{Characteristics of liquid pyrolysates}

Group organic geochemical parameters. Heated at $400{ }^{\circ} \mathrm{C}$ for $4 \mathrm{~h}$, the sample generated a total liquid pyrolysate and hydrocarbons of $1700 \mathrm{ppm}$ and $692 \mathrm{ppm}$, respectively (Table 3). The yields are consistent for source rock with good potential and support the assumption derived from an analysis of the immature oil shale. The presence of $\mathrm{Pt}(\mathrm{IV})$ - and $\mathrm{Ru}(\mathrm{III})$-ions significantly increases the yields of liquid pyrolysate and hydrocarbons, with a bit more pronounced effect of $\mathrm{Ru}(\mathrm{III})$-ion (Table 3). 


\begin{tabular}{|c|c|c|}
\hline Sample & Yield of liquid pyrolysates ${ }^{* *}(\mathrm{ppm})$ & ${\text { Yields of hydrocarbons }(\mathrm{HC})^{* *}(\mathrm{ppm})}^{*}$ \\
\hline S400 & 1700 & 692 \\
\hline SPt400 & 2700 & 1266 \\
\hline SRu400 & 2700 & 1376 \\
\hline Sample & $\mathrm{p}_{\mathrm{o}}$ & $\mathrm{p}$ \\
\hline S400 & 4.5 & 4.9 \\
\hline SPt400 & 4.5 & 5 \\
\hline SRu400 & 4.3 & 5.7 \\
\hline
\end{tabular}

${ }^{* *}$ relative to the bitumen-free sample; $\mathrm{p}_{\mathrm{o}}$, initial pressure; $\mathrm{p}$, pressure at the end of pyrolysis; $\mathrm{S} 400$ pyrolysate of bitumen-free oil shale at $400^{\circ} \mathrm{C}$; SPt400 - pyrolysate of bitumen-free oil shale at $400{ }^{\circ} \mathrm{C}+$ $\mathrm{H}_{2}\left[\mathrm{PtCl}_{6}\right]$; SRu400 - pyrolysate of bitumen-free oil shale at $400{ }^{\circ} \mathrm{C}+\mathrm{RuCl}_{3}$

Table 3. Values of group organic geochemical parameters in liquid pyrolysates

The catalytic effect of the used metal ions is based on them acting as Lewis acids and their high affinity for forming complexes with organic matter, both with the functional groups, such as carboxylic, hydroxyl, and amino groups, and the aromatic systems in the so-called sandwich compounds (Filipović \& Lipanović, 1995; Hagen, 2006; Sheldon et al., 2007). Apart from the liquid pyrolysate, the pyrolytic experiments also produced gaseous products that may be generated by direct degradation of kerogen or as secondary products of the degradation of liquid hydrocarbons. Gaseous products were not analyzed. However, their presence is proved by measuring pressure in the autoclave at the end of pyrolysis in relation to the initial pressure, which typically was $\sim 4.5 \mathrm{~atm}$ (Table 3). As in case of liquid products of pyrolysis, the increase of pressure/yield of gas products was somewhat more pronounced for $\mathrm{Ru}(\mathrm{III})$-ion compared to $\mathrm{Pt}(\mathrm{IV})$-ion. The more pronounced influence of $\mathrm{Ru}(\mathrm{III})$-ion may be explained by the fact that the $\mathrm{Ru}(\mathrm{III})$-ion forms exclusively octahedral complexes, while Pt(IV)-ion forms both octahedral and square planar complexes, because of which the $\mathrm{Ru}(\mathrm{III})$-ion has greater capacity for forming complexes with organic substance (Filipović \& Lipanović, 1995; Hagen, 2006; Sheldon et al., 2007).

Specific organic geochemical parameters based on biomarkers. All pyrolysates have similar $n$-alkane distributions in which $n$-alkanes $C_{17}-C_{23}$ are predominant (Fig. 7a), typical of organic matter of algal origin. CPI values for all the pyrolysates are close to 1, typical of a mature oil distribution (Table 4). Unlike bitumen in the immature oil shale, squalane is absent in the pyrolysates (Figs. 3a and 7a).

Values of $\mathrm{Pr} / \mathrm{Ph}$ ratio are higher than in the initial bitumen, which may be explained by the fact that degradation of kerogen during laboratory simulations results in uniform formation of both pristane and phytane (Tables 2 and 4; Stojanović et al., 2009, 2010). Compared to the pyrolysate of sample alone, the pyrolysates obtained in presence of metal ions have greater relative contents of pristane and phytane, which is reflected through the increase in $\operatorname{Pr} / n-\mathrm{C}_{17}$ and $\mathrm{Ph} / n-\mathrm{C}_{18}$ ratios and have higher values of $\mathrm{Pr} / \mathrm{Ph}$ ratios (Table 4). $\mathrm{Ru}(\mathrm{III})$-ion exhibits a somewhat more pronounced catalytic effect on both $n$-alkanes and isoprenoids, which also is observed at interpretation of group organic geochemical parameters (Tables 3 and 4).

Sterane distributions in pyrolysates obtained at $400{ }^{\circ} \mathrm{C}$ are typical for oils, which confirms once again good potential of the investigated sediment and shows that catagenesis has been successfully simulated by pyrolysis. Apart from the regular aaa(R)-steranes, $C_{27}-C_{29}$ isomers with thermodynamically more stable $\alpha \alpha \alpha(S)-, \alpha \beta \beta(R)-$, and $\alpha \beta \beta(S)$-configurations, as well 
as, typical geoisomers, $\beta a-$ and $a \beta$-diasteranes were present (Fig. $7 b$ ). All the three pyrolysates contain greater quantity of thermodynamically more stable $C_{29}$ and $C_{30}$ a $\beta$ hopanes, compared to corresponding $\beta a$-moretanes $\left(\mathrm{C}_{29} \mathrm{M} / \mathrm{C}_{29} \mathrm{H}\right.$ and $\mathrm{C}_{30} \mathrm{M} / \mathrm{C}_{30} \mathrm{H}$ below 1; Table 4), whereas unstable $\beta \beta$-hopanes and unsaturated hopenes were not identified. On the basis of mass spectra of corresponding peaks, the presence of Tm, Ts, $\mathrm{C}_{29} \mathrm{Ts}$ and 22(R and S)epimers $\mathrm{C}_{31}-\mathrm{C}_{33}$ homohopanes was determined in all pyrolysis (Fig. 7c).

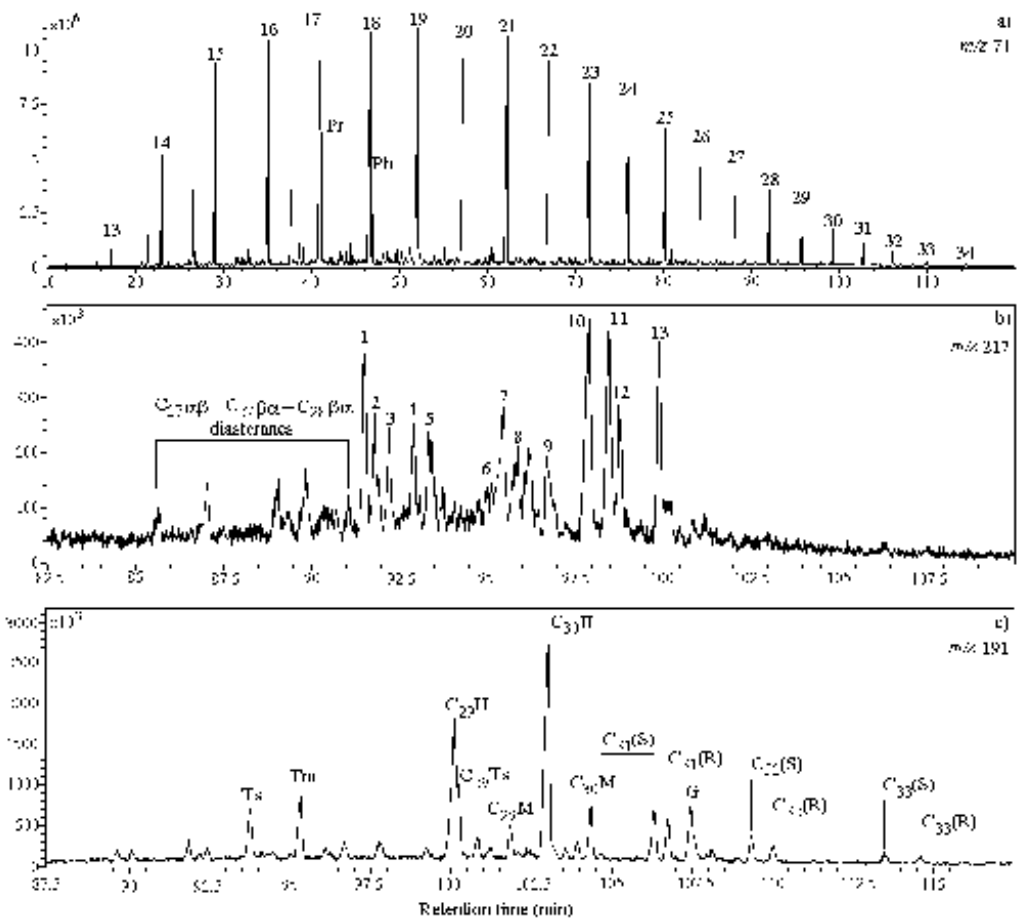

$1-\mathrm{C}_{27} 5 \mathrm{\alpha}(\mathrm{H}) 14 \alpha(\mathrm{H}) 17 \mathrm{\alpha}(\mathrm{H}) 20(\mathrm{~S})$-sterane $+\mathrm{C}_{28} 13 \alpha(\mathrm{H}) 17 \beta(\mathrm{H}) 20(\mathrm{~S})$-diasterane;

$2-\mathrm{C}_{27} 5 \mathrm{\alpha}(\mathrm{H}) 14 \beta(\mathrm{H}) 17 \beta(\mathrm{H}) 20(\mathrm{R})$-sterane $+\mathrm{C}_{29} 13 \beta(\mathrm{H}) 17 \mathrm{\alpha}(\mathrm{H}) 20(\mathrm{~S})$-diasterane;

$3-\mathrm{C}_{27} 5 \mathrm{a}(\mathrm{H}) 14 \beta(\mathrm{H}) 17 \beta(\mathrm{H}) 20(\mathrm{~S})$-sterane $+\mathrm{C}_{28} 13 \mathrm{a}(\mathrm{H}) 17 \beta(\mathrm{H}) 20(\mathrm{R})$-diasterane;

4 - $\mathrm{C}_{27} \mathrm{a}(\mathrm{H}) 14 \mathrm{\alpha}(\mathrm{H}) 17 \mathrm{a}(\mathrm{H}) 20(\mathrm{R})$-sterane; 5 - $\mathrm{C}_{29} 13 \beta(\mathrm{H}) 17 \mathrm{a}(\mathrm{H}) 20(\mathrm{R})$-diasterane;

$6-\mathrm{C}_{28} 5 \mathrm{a}(\mathrm{H}) 14 \mathrm{\alpha}(\mathrm{H}) 17 \mathrm{\alpha}(\mathrm{H}) 20(\mathrm{~S})$-sterane; $7-\mathrm{C}_{28} 5 \mathrm{a}(\mathrm{H}) 14 \beta(\mathrm{H}) 17 \beta(\mathrm{H}) 20(\mathrm{R})$-sterane +

$\mathrm{C}_{29} 13 \alpha(\mathrm{H}) 17 \beta(\mathrm{H}) 20(\mathrm{R})$-diasterane; 8 - $\mathrm{C}_{28} 5 \mathrm{a}(\mathrm{H}) 14 \beta(\mathrm{H}) 17 \beta(\mathrm{H}) 20(\mathrm{~S})$-sterane;

$9-\mathrm{C}_{28} 5 \mathrm{a}(\mathrm{H}) 14 \mathrm{a}(\mathrm{H}) 17 \mathrm{a}(\mathrm{H}) 20(\mathrm{R})$-sterane; $10-\mathrm{C}_{29} 5 \mathrm{a}(\mathrm{H}) 14 \mathrm{a}(\mathrm{H}) 17 \mathrm{a}(\mathrm{H}) 20(\mathrm{~S})$-sterane;

11 - $\mathrm{C}_{295} \mathrm{\alpha}(\mathrm{H}) 14 \beta(\mathrm{H}) 17 \beta(\mathrm{H}) 20(\mathrm{R})$-sterane; 12 - $\mathrm{C}_{29} 5 \mathrm{a}(\mathrm{H}) 14 \beta(\mathrm{H}) 17 \beta(\mathrm{H}) 20(\mathrm{~S})$-sterane;

13 - $\mathrm{C}_{29} \mathrm{a} \mathrm{a}(\mathrm{H}) 14 \mathrm{a}(\mathrm{H}) 17 \mathrm{a}(\mathrm{H}) 20(\mathrm{R})$-sterane;

Ts - $\mathrm{C}_{27} 18 \mathrm{a}(\mathrm{H})-22,29,30$-trisnorneohopane; Tm - $\mathrm{C}_{27} 17 \mathrm{a}(\mathrm{H})-22,29,30$-trisnorhopane;

$\mathrm{C}_{29} \mathrm{H}-\mathrm{C}_{29} 17 \mathrm{a}(\mathrm{H}) 21 \beta(\mathrm{H})-30$-norhopane; $\mathrm{C}_{29} \mathrm{Ts}-\mathrm{C}_{29} 18 \mathrm{a}(\mathrm{H})$-30-norneohopane; $\mathrm{C}_{29} \mathrm{M}-\mathrm{C}_{29} 17 \beta(\mathrm{H}) 21 \mathrm{a}(\mathrm{H})$ moretane; $\mathrm{C}_{30} \mathrm{H}-\mathrm{C}_{30} 17 \mathrm{a}(\mathrm{H}) 21 \beta(\mathrm{H})$-hopane; $\mathrm{C}_{30} \mathrm{M}-\mathrm{C}_{30} 17 \beta(\mathrm{H}) 21 \mathrm{a}(\mathrm{H})$-moretane; $\mathrm{C}_{31}(\mathrm{~S})$ -

$\mathrm{C}_{31} 17 \mathrm{a}(\mathrm{H}) 21 \beta(\mathrm{H}) 22(\mathrm{~S})$-hopane; $\mathrm{C}_{31}(\mathrm{R})$ - $\mathrm{C}_{31} 17 \mathrm{a}(\mathrm{H}) 21 \beta(\mathrm{H}) 22(\mathrm{R})$-hopane; $\mathrm{G}$ - gammacerane; $\mathrm{C}_{32}(\mathrm{~S})$ -

$\mathrm{C}_{32} 17 \mathrm{a}(\mathrm{H}) 21 \beta(\mathrm{H}) 22(\mathrm{~S})$-hopane; $\mathrm{C}_{32}(\mathrm{R})-\mathrm{C}_{32} 17 \mathrm{a}(\mathrm{H}) 21 \beta(\mathrm{H}) 22(\mathrm{R})$-hopane; $\mathrm{C}_{33}(\mathrm{~S})-\mathrm{C}_{33} 17 \mathrm{a}(\mathrm{H}) 21 \beta(\mathrm{H}) 22(\mathrm{~S})-$

hopane; $\mathrm{C}_{33}(\mathrm{R})-\mathrm{C}_{33} 17 \alpha(\mathrm{H}) 21 \beta(\mathrm{H}) 22(\mathrm{R})$-hopane; for other peak assignments, see legend, Fig. 3

Fig. 7. GC-MS ion fragmentogram of $n$-alkanes and isoprenoids, $m / z 71$ (a), steranes, $m / z 217$

(b) and terpanes, $m / z 191$ (c) from saturated fraction of pyrolysate S400, typical for all

pyrolysates 
Values of the most used sterane maturation parameters based on the ratios of $\mathrm{C}_{29}$ sterane isomers, $C_{29} \alpha \beta \beta(R) / C_{29}(\alpha \beta \beta(R)+\alpha a \alpha(R))$ and $C_{29} \alpha \alpha \alpha(S) / C_{29} \alpha \alpha \alpha(S+R)$ in pyrolysates are lower than quilibrium values. On the other hand, values for $C_{31}(S) / C_{31}(S+R)$-homohopanes show that in isomerisation $22(\mathrm{R}) \rightarrow 22(\mathrm{~S})$ the equilibria has been achieved in all pyrolysates (Table 4). Based on these results, it may be assumed that during pyrolysis at $400{ }^{\circ} \mathrm{C}$ the investigated oil shale reached the value of vitrinite reflectance equivalence between 0.60 and $0.80 \%$ (Peters et al., 2005). All pyrolysates obtained in presence of metal ions are characterised with higher values of $\mathrm{C}_{29} \mathrm{M} / \mathrm{C}_{29} \mathrm{H}, \mathrm{C}_{30} \mathrm{M} / \mathrm{C}_{30} \mathrm{H}$ ratios, and lower values of $\mathrm{C}_{29} \mathrm{aqa}(\mathrm{S}) / \operatorname{aqa}(\mathrm{S}+\mathrm{R}), \mathrm{Ts} /(\mathrm{Ts}+\mathrm{Tm}), \mathrm{C}_{29} \mathrm{Ts} / \mathrm{C}_{29} \mathrm{H}$ ratios compared to pyrolysate of pure oil shale, especially in case of $\mathrm{Ru}(\mathrm{III})$-ion (Table 4$)$. The only exception among the sterane and terpane maturation parameters is the $C_{29} \alpha \beta \beta(R) / C_{29}(\alpha \beta \beta(R)+\alpha \alpha \alpha(R))$ ratio (Table 4). The reported observations lead to the assumption that metal ions, especially in case of $\mathrm{Ru}(\mathrm{III})$ ion have greater impact on kerogen degradation, which directly reflects on the increase in the quantity of hydrocarbons, than on isomerisation reactions: moretanes $\rightarrow$ hopanes, hopanes $\rightarrow$ neohopanes and $\mathrm{C}_{29}$ aaa $(\mathrm{R}) \rightarrow \mathrm{C}_{29}$ aaa $(\mathrm{S})$. This conclusion is not surprising since kerogen contains functional groups for which the used metal ions show much stronger affinity, compared to saturated hydrocarbons.

\begin{tabular}{|c|c|c|c|c|c|c|}
\hline Sample & CPI & $\begin{array}{l}\mathrm{Pr} / \\
\mathrm{Ph}\end{array}$ & $\begin{array}{l}\mathrm{Pr} / \\
n-\mathrm{C}_{17}\end{array}$ & $\begin{array}{l}\mathrm{Ph} / \\
n-\mathrm{C}_{18}\end{array}$ & $\begin{array}{c}\mathrm{C}_{30} \mathrm{M} / \\
\mathrm{C}_{30} \mathrm{H}\end{array}$ & $\begin{array}{c}\mathrm{C}_{29} \mathrm{M} / \\
\mathrm{C}_{29} \mathrm{H}\end{array}$ \\
\hline S400 & 1.04 & 1.12 & 0.23 & 0.22 & 0.26 & 0.24 \\
\hline SPt400 & 1.03 & 1.29 & 0.46 & 0.37 & 0.31 & 0.35 \\
\hline SRu400 & 1.04 & 1.50 & 0.66 & 0.50 & 0.51 & 0.52 \\
\hline E.V. & / & / & / & / & $0.05-0.15$ & / \\
\hline Sample & $\begin{array}{c}\mathrm{C}_{31}(\mathrm{~S}) / \\
\mathrm{C}_{31}(\mathrm{~S}+\mathrm{R})\end{array}$ & $\begin{array}{c}\text { Ts/ } \\
(\mathrm{Ts}+\mathrm{Tm})\end{array}$ & $\begin{array}{c}\mathrm{G} \times 100 / \\
\mathrm{C}_{30} \mathrm{H}\end{array}$ & $\begin{array}{c}\mathrm{C}_{29} \mathrm{aaa}(\mathrm{S}) / \\
\mathrm{C}_{29} \mathrm{aqa}(\mathrm{S}+\mathrm{R})\end{array}$ & \multicolumn{2}{|c|}{$C_{29} \alpha \beta \beta(R) / C_{29}(\alpha \beta \beta(R)+\alpha \alpha a(R))$} \\
\hline S400 & 0.57 & 0.42 & 25.88 & 0.49 & \multicolumn{2}{|c|}{0.52} \\
\hline $\mathrm{SPt} 400$ & 0.59 & 0.39 & 23.62 & 0.46 & \multicolumn{2}{|c|}{0.54} \\
\hline SRu400 & 0.57 & 0.33 & 23.10 & 0.43 & \multicolumn{2}{|c|}{0.58} \\
\hline E.V. & $0.57-0.62$ & / & / & $0.52-0.55$ & \multicolumn{2}{|c|}{$0.67-0.71$} \\
\hline
\end{tabular}

for peak assignments, see legends, Figs. 3 and 7; E.V. - equilibrium value (Peters et al., 2005)

Table 4. Values of parameters calculated from distributions and abundances of biomarkers in pyrolysates

Specific organic geochemical parameters based on alkylaromatics. Liquid pyrolysis products have alkyl-naphthalene and phenanthrene distributions typical of mature oil (Figs. 8 and 9).

Values of the naphthalene maturation parameters in pyrolysates suggest that the metal ions have a catalytic effect on isomerisations of methyl groups that lead to the generation of more thermodynamically stable naphthalene isomers. Again, the Ru(III)-ion exhibits a somewhat more pronounced effect compared to $\mathrm{Pt}(\mathrm{IV})$-ion (Table 5). Maturation parameters based on isomerisation of methyl phenanthrene groups from a- to $\beta$-positions, as well as on the reactions of methylation of phenanthrene ring are higher in pyrolysates obtained in the presence of $\mathrm{Pt}(\mathrm{IV})$ - and $\mathrm{Ru}(\mathrm{III})$-ions, than in the pyrolysate of pure oil shale. Thus, $\mathrm{Pt}(\mathrm{IV})$ - and $\mathrm{Ru}(\mathrm{III})$-ions have catalytic effect on both the processes (isomerisation $\alpha \rightarrow \beta$ and methylation) 
at $400{ }^{\circ} \mathrm{C} . \mathrm{Ru}(\mathrm{III})$-ion showed more pronounced effect on the reactions of isomerisation of methylphenanthrenes (parameters MPI 1 and MPI 3), and Pt(IV)-ion on the methylation processes, especially in case of methylphenanthrenes to dimethylphenanthrenes transformation (parameters PAI 1, PAI 2 and DMR) (Table 5).

Applying the equation Ro $=0.6 \times$ MPI $1+0.37$ (Radke \& Welte, 1983), vitrinite reflectance equivalent of $0.70 \%$ for pyrolysate of pure oil shale at $400{ }^{\circ} \mathrm{C}$ is calculated. This Ro value is in full agreement with the results obtained at interpretation of terpane and sterane biomarkers. In the presence of metal ions, under the same conditions, the organic matter of the analysed shale would attain the value of vitrinite equivalent of approximately $0.8 \%$ (Table 5 ).

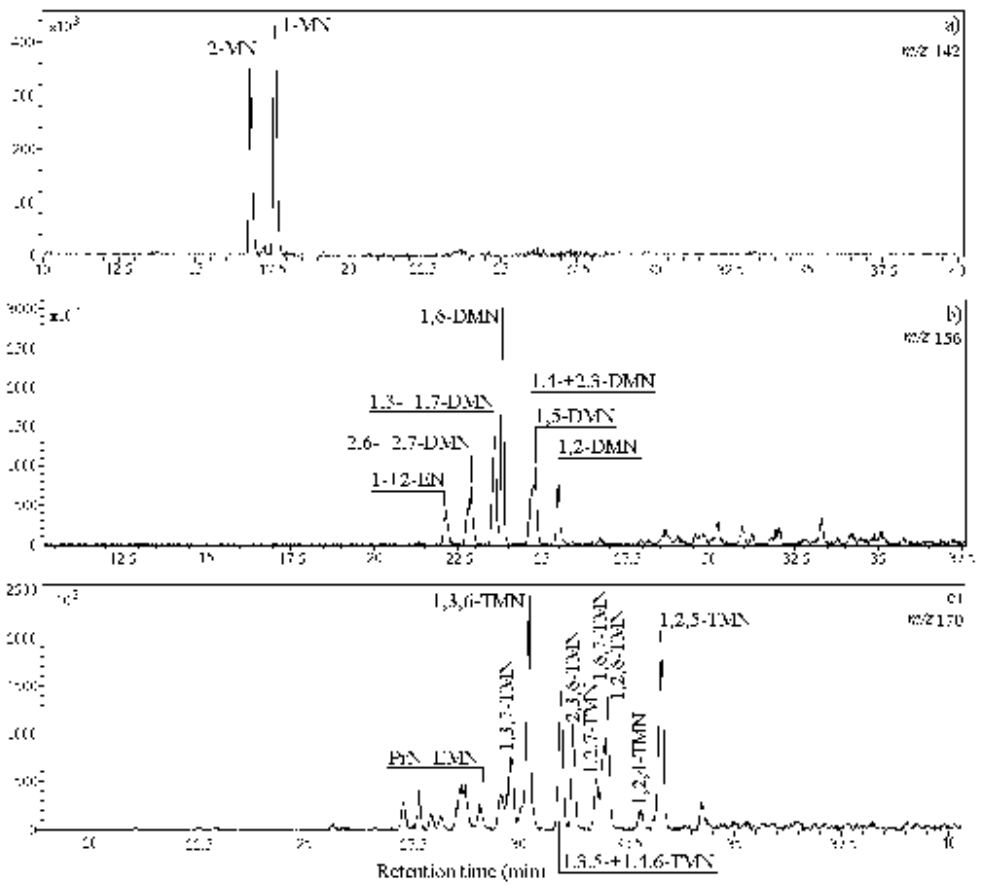

MN - methylnaphthalene; DMN - dimethylnaphthalene; TMN - trimethylnaphthalene; PrN - propylnaphthalene; EMN - ethylmethylnaphthalene

Fig. 8. GC-MS ion fragmentograms of MN, $m / z 142$ (a), DMN, m/z 156 (b) and TMN, $m / z 170$ (c) from aromatic fraction of pyrolysate $\mathrm{S} 400$, typical for all pyrolysates

Differences in values of alkylaromatics maturity ratios obtained in the presence of metal ions in comparison to pyrolysate of the shale without metals are more pronounced in naphthalene, compared to phenanthrene parameters (Table 5). Comparing these results to maturation ratios calculated from distribution and abundance of saturated biomarkers, we conclude that $\mathrm{Pt}(\mathrm{IV})$ - and $\mathrm{Ru}(\mathrm{III})$-ions have much greater influence on maturation changes on the planar systems (naphthalene and phenanthrene rings), than on isomerisations in the polycyclic alkanes, steranes and terpanes (Tables 4 and 5). The above observation is in agreement with the theoretical knowledge, as it is known that transition metal ions acting as 
Lewis acids show an affinity for aromatic systems, and that they form stable complexes with aromatic ligands in the form of sandwich compounds (Hagen, 2006; Radke, 1987).

\begin{tabular}{|c|c|c|c|c|c|c|c|}
\hline Sample & MNR & DNR 1 & $\mathrm{DNx}$ & $\alpha / \beta D N 1$ & TNR 3 & $\alpha / \beta \mathrm{TN} 1$ & $\mathrm{TNy}$ \\
\hline S400 & 0.63 & 1.44 & 2.28 & 1.61 & 1.14 & 0.82 & 2.27 \\
\hline SPt400 & 0.73 & 1.82 & 3.09 & 0.99 & 1.31 & 0.70 & 2.31 \\
\hline SRu400 & 0.77 & 2.35 & 2.95 & 1.07 & 1.67 & 0.57 & 2.44 \\
\hline Sample & MPI 1 & MPI 3 & Ro & DMPI 1 & PAI 1 & PAI 2 & DMR \\
\hline S400 & 0.49 & 0.91 & 0.70 & 0.41 & 1.07 & 0.57 & 0.53 \\
\hline SPt400 & 0.62 & 0.97 & 0.77 & 0.75 & 1.45 & 1.49 & 1.03 \\
\hline SRu400 & 0.63 & 1.01 & 0.78 & 0.70 & 1.43 & 1.40 & 0.98 \\
\hline
\end{tabular}

$\mathrm{MNR}=2-\mathrm{MN} / 1-\mathrm{MN} ; \mathrm{DNR} 1$ = (2,6-+2,7-DMN)/1,5-DMN; DNx = (1,3-+1,6-+1,7-DMN)/(1,4-+1,5-+2,3$\mathrm{DMN}) ; \alpha / \beta \mathrm{DN} 1=(1,4-+1,5-+2,3-\mathrm{DMN}) /(2,6-+2,7-\mathrm{DMN}) ; \mathrm{TNR} 3=1,3,6-\mathrm{TMN} / 1,2,5-\mathrm{TMN} ; \alpha / \beta \mathrm{TN} 1=$ $(1,2,4-+1,2,5-\mathrm{TMN}) /(1,2,6-+1,2,7-+1,6,7-+2,3,6-\mathrm{TMN}) ; \mathrm{TNy}=(1,3,6-+1,3,7-\mathrm{TMN}) /(1,3,5-+1,4,6-\mathrm{TMN})$; MPI 1 = 1,5 x (2-+3-MP)/(P+1-+9-MP); MPI 3 = (2-+3-MP)/(1-+9-MP); Ro = $0.6 \times$ MPI 1 + 0.37; DMPI 1 $=4 \times(2,6-+2,7-+3,5-+3,6-\mathrm{DMP}+1-+2-+9-\mathrm{EP}) /(\mathrm{P}+1,3-+1,6-+1,7-+2,5-+2,9-+2,10-+3,9-+3,10-\mathrm{DMP})$; PAI 1 = (1-+2-+3-+9-MP) $/ \mathrm{P} ; \mathrm{PAI} 2=\Sigma \mathrm{DMP} / \mathrm{P} ; \mathrm{DMR}=\Sigma \mathrm{DMP} / \Sigma \mathrm{MP}$ for peak assignments, see legends, Figs. 8 and 9

Table 5. Values of alkylaromatics maturation parameters in pyrolysates

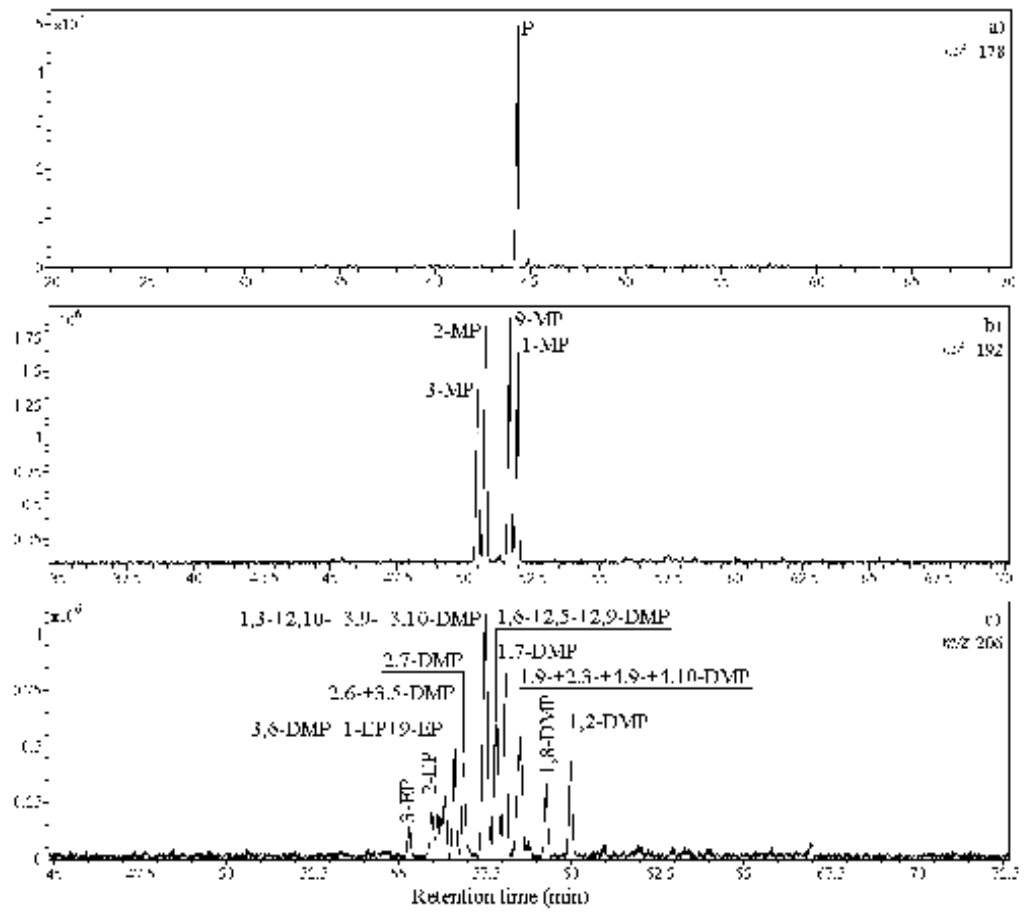

$\mathrm{P}$ - phenanthrene; MP - methylphenanthrene; DMP - dimethylphenanthrene; EP - ethylphenanthrene

Fig. 9. GC-MS ion fragmentograms of P, m/z 178 (a), MP, $m / z 198$ (b) and DMP, m/z 206 (c) from aromatic fraction of pyrolysate $\mathrm{S} 400$, typical for all pyrolysates 
Assessment of the conditions for achieving early catagenesis. Pyrolysis at $400{ }^{\circ} \mathrm{C}$ of the investigated oil shale achieved oil generation at a vitrinite reflectance equivalent of $\sim 0.7 \%$. Applying a generalized diagram that relates Ro, depth and a regional geothermal gradient (Suggate, 1998) ranging between 40 and $50{ }^{\circ} \mathrm{C} / \mathrm{km}$ (Kostić, 2010), the minimum depth of 2300-2900 m was estimated at which the shale would become a thermally mature source rock (Fig. 10). The minimum temperature necessary for catagenetic generation of hydrocarbons (temperature $=$ depth $\mathrm{x}$ geothermal gradient + annual mean surface temperature; Suggate, 1998) was calculated at $103{ }^{\circ} \mathrm{C}\left(\mathrm{t}=2.3 \times 40+11=103{ }^{\circ} \mathrm{C}\right)$. Using the basin-independent equation $\mathrm{T}=(\operatorname{lnRo}+1.68) / 0.0124$ (Barker \& Pawlewicz, 1994), and Ro value of $0.70 \%$ is estimated to be at $107{ }^{\circ} \mathrm{C}$. Estimated temperature of hydrocarbons generation and necessary depth are in good agreement with corresponding data for the active source rocks in the region (Dragaš et al., 1991; Jovančićević et al., 2002; Kostić, 2010; Mrkić et al., 2011).

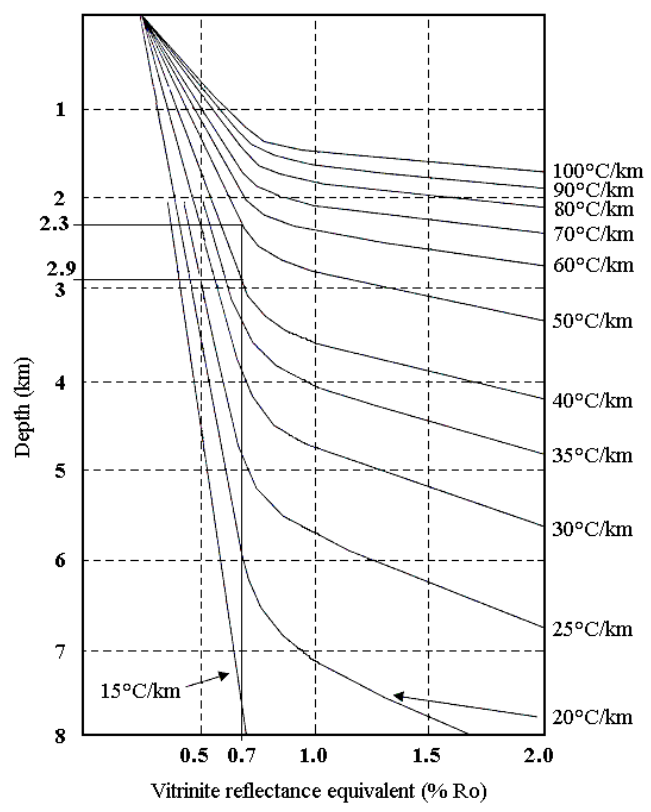

Fig. 10. Depth vs. vitrinite reflectance vs. geothermal gradient (according to Suggate, 1998); $\%$ of Ro value calculated in this study, and corresponding depth are indicated

\section{Conclusions}

The differences in geochemical and mineralogical characteristics of the sediments indicate that the palaeoconditions in the sedimentation area changed over the time, which allow defining four different depth intervals in the drillhole Val-1. In certain periods sedimentation occured under very specific conditions. Sediments from 15-75 m depth interval were formed under the high salinity conditions, whereas sediments from depths $360-400 \mathrm{~m}$ were deposited in the conditions of the high alkalinity. Sediments from 15-75 m depths are characterized by the presence of searlesite and high amount of immature algal 
OM with good generative liquid hydrocarbon potential, deposited under reducing environment. From the organic-geochemical point of view, depth interval $200-400 \mathrm{~m}$ is less interesting due to the lower OM content with low liquid hydrocarbons generation potential. Interval at depths from 360 to $400 \mathrm{~m}$ is significant, since sediments may contain lithiumbearing clay minerals.

Pyrolytic experiments showed that oil shale from depth interval 15 to $75 \mathrm{~m}$ in a catagenetic stage may be a source of liquid hydrocarbons. Pt(IV)- and $\mathrm{Ru}(\mathrm{III})$-ions, demonstrated significant positive effects on the yields of total liquid pyrolysate and corresponding hydrocarbons. The used metal ions had much greater influence on maturity changes on planar systems (naphthalene and phenanthrene rings) than on isomerisations in the molecules of polycyclic alkanes. Values of terpane and sterane and phenanthrene maturation parameters indicate that through pyrolysis at $400{ }^{\circ} \mathrm{C}$ the investigated sample reaches the value of vitrinite reflectance equivalent of approximately $0.70 \%$.

It was estimated that the investigated oil shale should be found at depth of $2300-2900 \mathrm{~m}$ in order to become active source rock. The calculated minimum temperature necessary for catagenetic hydrocarbon generation is between 103 and $107^{\circ} \mathrm{C}$.

\section{Acknowledgment}

Investigations within this study were done in cooperation with the company Rio Tinto Exploration from Serbia. The study was partly financed by the Ministry of Science and Technological Development of the Republic of Serbia (Projects number 146008 and 176006).

\section{References}

Alonso, R.N. (1999). On the origin of La Puna Borates. Acta Geologica Hispanica, Vol.34, No.23, (April-September 1999), pp. 141-166, ISSN 1695-6133

Aggarwal, J.K.; Palmer, M.R.; Bullen, T.D.; Arnórsson, S. \& Ragnarsdóttir, K.V. (2000). The boron isotope systematics of Icelandic geothermal waters: 1. meteoric water charged systems. Geochimica et Cosmochimica Acta, Vol.64, No.4, (February 2000), pp. 579-585, ISSN 0016-7037

Anderson, R.; Kates, M.; Baedecker, M.J.; Kaplan, I.R. \& Ackman, R.G. (1977). The stereoisomeric composition of phytanyl chains in lipids of Dead Sea sediments. Geochimica et Cosmochimica Acta, Vol.41, No.9, (September 1977), pp. 1381-1390, ISSN 0016-7037

Barker, C.E. \& Pawlewicz, M.J. (1994). Calculation of vitrinite reflectance from thermal histories and peak temperatures. A comparison of Methods, In: Vitrinite Reflectance as a Maturity Parameter: Applications and Limitations, Mukhopadhyay P.K \& Dow, W.G. (Eds.), pp. 216-222, American Chemical Society, ISBN 0-8412-2994-5, Washington, USA

Blumer, M. (1957). Removal of Elemental Sulfur from Hydrocarbon Fractions. Analytical Chemistry, Vol.29, No.7, (July 1957), pp. 1039-1041, ISSN 1520-6882

Brassell, S.C.; Sheng, G.; Fu, J. \& Eglinton, G. (1988). Biological markers in lacustrine Chinese oil shales. In: Lacustrine and Petroleum Source Rocks, Fleet, A.J., Kelts, K. \& Talbot, M.R., (Eds.), pp. 299-308, ISBN 0-632-01803-8, London, UK 
Bray, E.E. \& Evans, E.D. (1961). Distribution on $n$-paraffins as a clue to recognition of source beds. Geochimica et Cosmochimica Acta, Vol.22, No.1, (February 1961), pp. 2-15, ISSN 0016-7037

de Rosa, M.; Gambacorta, A. \& Gliozzi, A. (1986). Structure, Biosynthesis and physicochemical properties of archaebacterial lipids. Microbiological Reviews/Microbiology and Molecular Biology Reviews, Vol.50, No.1, (March 1986), pp. 70-80, ISSN 0146-0749/1092-2172

Dolić, D. (1984). Biostratigraphic contribution to the knowledge of the Middle Miocene lacustrine beds from Valjevo basin. Protocol SGD, Vol.1, pp. 63-67 (In Serbian with summary in German)

Dragaš, M.; Opić, I. \& Britvić, V. (1991). Temperature distribution analysis in INA Naftaplin's exploration provinces based on the temperature measurings. Nafta, Vol.42, No.10, (October 1991), pp. 383-398, ISSN 0027-755X (in Croatian with summary in English).

Filipović, I. \& Lipanović, S. (1995). General and Inorganic Chemistry (9th edition), Školska knjiga, ISBN 953-0-30905-8, Zagreb, Croatia (in Croatian)

Floyd, P.A.; Helvaci, C. \& Mittwede, S.K. (1998). Geochemical discrimination of volcanic rocks associated with borate deposits: an exploration tool? Journal of Geochemical Exploration, Vol.60, No.3, (March 1998), pp. 185-205, ISSN 0375-6742

Grice, K.; Schouten, S.; Nissenbaum, A.; Charrach, J. \& Sinninghe Damsté, J. (1998). Isotopically heavy carbon in the $C_{21}$ to $C_{25}$ regular isoprenoids in halite-rich deposits from the Sdom Formation, Dead Sea Basin, Israel. Organic Geochemistry, Vol.28, No.6, (April 1998), pp. 349-359, ISSN 0146-6380

Grim, R.E. (1968). Clay Mineralogy (2nd edition), McGraw-Hill Book Co, ISBN 9780070248366, New York, USA

Hagen, J. (2006). Industrial Catalysis. A Practical Approach (2nd edition), WILEY-VCH Verlag GmbH \& Co. KGaA, ISBN 978-3-527-31144-6, Weinheim, Germany

Helvaci, C. \& Alonso, R.N. (2000). Borate Deposits of Turkey and Argentina; A Summary and Geological Comparison. Turkish Journal of Earth Sciences, Vol.9, No.1, (April 2000), pp. 1-27, ISSN 1300-0985

$\mathrm{Hu}$, J.; Venkatesh, K.R.; Tierney, J.W. \& Wender, I. (1994). Reactions of aromatics and naphthenes with alkanes over a $\mathrm{Pt} / \mathrm{ZrO}_{2} / \mathrm{SO}_{4}$ catalyst. Applied catalysis A: General, Vol.114, No.2, (July 1994), pp. L179-L186, ISSN 0926-860X

Jovančićević, B.; Vučelić, D.; Šaban, M.; Wehner, H. \& Vitorović, D. (1993). Investigation of the catalytic effects of indigenous minerals in the pyrolysis of Aleksinac oil shale substrates: Steranes, triterpanes and triaromatic steroids in the pyrolysates. Organic Geochemistry, Vol.20, No.1, (January 1993), pp. 69-76, ISSN 0146-6380

Jovančićević, B.; Wehner, H.; Scheeder, G.; Stojanović, K.; Šajnović, A.; Cvetković, O.; Ercegovac, M. \& Vitorović, D. (2002). Search for source rocks of the crude oils of the Drmno depression (southern part of the Pannonian Basin, Serbia). Journal of the Serbian Chemical Society, Vol.67, No. 8-9, (August-September 2002), pp. 553-566, ISSN 0352-5139 
Jovanović, O.; Grgurović, D. \& Zupančić, N. (1994). The neogene sediments in Valjevomionica basin. Geology, Series A, B (Hydrogeology and Engineering Geology), Vol.46, pp. 207-222 (In Serbian with Summary in English)

Kawaguchi, T.; Sugimoto, W.; Murakami, Y. \& Takasu, Y. (2005). Particle growth behavior of carbon-supported $\mathrm{Pt}, \mathrm{Ru}, \mathrm{PtRu}$ catalysts prepared by an impregnation reductivepyrolysis method for direct methanol fuel cell anodes. Journal of Catalysis, Vol.229, No.1, (January 2005), pp. 176-184, ISSN 0021-9517

Kazanc1, N.; Toprak, Ö.; Leroy, S.A.G.; Öncel, S.; Ileri Ö.; Emre Ö.; Costa, P.; Erturaç, K. \& McGee, E. (2006). Boron content of Lake Ulubat sediment: A key to interpret the morphological history of NW Anatolia, Turkey. Applied Geochemistry, Vol.21, No.1, (January 2006), pp. 134-151, ISSN 0883-2927

Kostić, A. (2010). Thermal evolution of organic matter and petroleum generation modelling in the Pannonian basin (Serbia), University of Belgrade, Faculty of Mining and Geology \& "Planeta print", ISBN 978-86-7352-221-0, Belgrade, Serbia (in Serbian with summary in English)

Mrkić, S.; Stojanović, K.; Kostić, A.; Nytoft, H.P. \& Šajnović A. (2011). Organic geochemistry of Miocene source rocks from the Banat Depression (SE Pannonian Basin, Serbia). Organic Geochemistry, Vol.42, No.6, (July 2011), pp. 655-677, ISSN 0146-6380

$\mathrm{Ng}$, S.L. \& King, R.H. (2004). Geochemistry of lake sediments as a record of environmental change in a high Arctic watershed. Chemie der Erde Geochemistry, Vol.64, No.3, (September 2004), pp. 257-275, ISSN 0009-2819

Peng, Q.; Palmer, M. \& Lu, J. (1998). Geology and geochemistry of the Paleoproterozoic borate deposits in Liaoning-Jilin, northeastern China: evidence of metaevaporites. International Journal of Salt Lake Research/Hydrobiologia, Vol.381, No.1-3, (September 1998), pp. 51-57, ISSN 0018-8158

Peters, K.E.; Cunningham, A.E.; Walters, C.C.; Jigang, J. \& Fan, Z. (1996). Petroleum systems in the Jiangling-Dangyang area, Jianghan basin, China. Organic Geochemistry, Vol.24, No.10-11, (October - November 1996), pp. 1035-1060, ISSN 0146-6380

Peters, K.E.; Walters, C.C. \& Moldowan, J.M. (2005). The Biomarker Guide, Volume 2: Biomarkers and Isotopes in the Petroleum Exploration and Earth History, Cambridge University Press, ISBN 978-0-521-83762-0, Cambridge, UK

Radke, M. \& Welte, D.H. (1983). The methylphenanthrene index (MPI): a maturity parameter based on aromatic hydrocarbons. In: Advances in Organic Geochemistry 1981, Bjorøy, M. et al. (Eds.), pp. 504-512, John Wiley \& Sons Limited, ISBN 0471 262293 , Chichester, UK

Radke, M. (1987). Organic geochemistry of aromatic hydrocarbons, In: Advances in Petroleum Geochemistry, Radke M. (Ed.), pp 141-205, Academic Press, ISBN 0-12-032009-9, London, UK

Remy, R. \& Ferrell, R. (1989). Distribution and origin of analcite in marginal lacustrine mudstones of the Green river formation, South-central Uinta basin, Utah. Clays and Clay minerals, Vol.37, No.5, (October 1989), pp. 419-432, ISSN 1552-8367

Sheldon, R.; Arends, I. \& Hanefeld, U. (2007). Green Chemistry and Catalysis, WILEY-VCH Verlag GmbH \& Co. KGaA, ISBN 978-3-527-30715-9, Weinheim, Germany 
Sinninghe Damsté, J.S.; Keing, F.; Koopmans, M.P.; Koster, J.; Schouten, S.; Hayes, J.M. \& de Leeuw, J.W. (1995). Evidence for gammacerane as an indicator of water column stratification. Geochimica et Cosmochimica Acta, Vol.59, No.9, (May 1995), pp. 18951900, ISSN 0016-7037

Stojanović, K.; Jovančićević, B.; Šajnović, A.; Sabo, T.; Vitorović, D.; Schwarzbauer, J. \& Golovko, A. (2009). Pyrolysis and Pt(IV)- and $\mathrm{Ru}(\mathrm{III})$-ion catalyzed pyrolysis of asphaltenes in organic geochemical investigation of a biodegraded crude oil (Gaj, Serbia). Fuel, Vol.88, No.2, (February 2009), pp. 287-296, ISSN 0016-2361

Stojanović, K.; Šajnović, A.; Sabo, T.; Golovko, A. \& Jovančićević, B. (2010). Pyrolysis and Catalyzed Pyrolysis in the Investigation of a Neogene Shale Potential from ValjevoMionica Basin, Serbia. Energy Fuel, Vol.24, No.8, (August 2010), pp. 4357-4368, ISSN 1520-5029

Suggate, R.P. (1998). Relations between depth of burial, vitrinite reflectance and geothermal gradient. Journal of Petroleum Geology, Vol.21, No.1 (January 1998), pp. 5-32, ISSN 0141-6421

Šajnović, A.; Simić, V.; Jovančićević, B.; Cvetković, O.; Dimitrijević, R. \& Grubin, N. (2008a). Sedimentation History of Neogene Lacustrine Sediments of Sušeočka Bela Stena Based on Geochemical Parameters (Valjevo-Mionica Basin, Serbia). Acta Geologica Sinica - English Edition, Vol.82, No.6, (December 2008), pp. 1201-1212, ISSN 17556724

Šajnović, A.; Stojanović, K.; Jovančićević, B. \& Cvetković, O. (2008b). Biomarker distributions as indicators for the depositional environment of lacustrine sediments in the Valjevo-Mionica basin (Serbia). CHEMIE der ERDE GEOCHEMISTRY, Vol.68, No.4, (September 2008), pp. 395-411, ISSN 0009-2819

Šajnović, A.; Stojanović, K.; Jovančićević, B. \& Golovko, A. (2009). Geochemical investigation and characterisation of Neogene sediments from Valjevo-Mionica Basin (Serbia). Environmental Geology, Vol.56, No.8, (February 2009), pp. 1629-1641, ISSN 1866-6280

Šajnović, A.; Stojanović, K.; Pevneva, G.; Golovko, A. \& Jovančićević, B. (2010). Origin, Organic Geochemistry, and Estimation of the Generation Potential of Neogene Lacustrine Sediments from the Valjevo-Mionica Basin, Serbia. Geochemistry International, Vol.48, No.7, (July 2010), pp. 678-694, ISSN 0016-7029

ten Haven, H.L.; de Leeuw, J.W.; Sinninghe Damsté, J.S.; Schenk, P.A.; Palmer, S.E. \& Zumberge, J.E. (1988). Application of biological markers in the recognition of paleohypersaline environment. In: Lacustrine and Petroleum Source Rocks, Fleet, A.J., Kelts, K. \& Talbot, M.R., (Eds.), pp. 123-130, ISBN 0-632-01803-8, London, UK

Valero-Garcés, B.L.; Grosjean, M.; Kelts, K.; Schreier, H. \& Messerli, B. (1999). Holocene lacustrine deposition in the Atacama Altiplano: facies models, climate and tectonic forcing. Palaeogeography, Palaeoclimatology, Palaeoecology, Vol.151, No.1-3, (July 1999), pp. 101-125, ISSN 0031-0182

Volkman, J.K. \& Maxwell, J.R. (1988). Acyclic isoprenoids as biological markers, In: Lacustrine and Petroleum Source Rocks, Fleet, A.J., Kelts, K. \& Talbot, M.R., (Eds.), pp. 103-122, Blackwell Scientific Publications, ISBN 0-632-01803-8, London, UK

Volkman, J.K. (2003). Sterols in microorganisms. Applied Microbiology and Biotechnology, Vol.60, No.5, (January 2003), pp. 496-506, ISSN 0340-2118 
Yudovich, Ya.E. \& Ketris, M.P. (2005). Arsenic in coal: a review. International Journal of Coal Geology, Vol.61, No.3-4, (February 2005), pp. 141-196, ISSN 0166-5162

Wang, R. \& Fu, J. (1997). Variability in biomarkers of different saline basins in China. International Journal of Salt Lake Research/Hydrobiologia, Vol.6, No.1, (March 1997), pp. 25-53, ISSN 0018-8158 


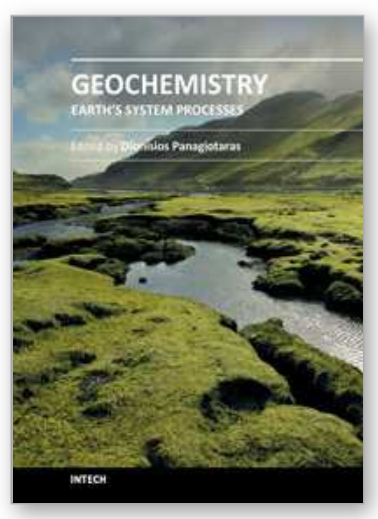

\author{
Geochemistry - Earth's System Processes \\ Edited by Dr. Dionisios Panagiotaras
}

ISBN 978-953-51-0586-2

Hard cover, 500 pages

Publisher InTech

Published online 02, May, 2012

Published in print edition May, 2012

This book brings together the knowledge from a variety of topics within the field of geochemistry. The audience for this book consists of a multitude of scientists such as physicists, geologists, technologists, petroleum engineers, volcanologists, geochemists and government agencies. The topics represented facilitate as establishing a starting point for new ideas and further contributions. An effective management of geological and environmental issues requires the understanding of recent research in minerals, soil, ores, rocks, water, sediments. The use of geostatistical and geochemical methods relies heavily on the extraction of this book. The research presented was carried out by experts and is therefore highly recommended to scientists, underand post-graduate students who want to gain knowledge about the recent developments in geochemistry and benefit from an enhanced understanding of the dynamics of the earth's system processes.

\title{
How to reference
}

In order to correctly reference this scholarly work, feel free to copy and paste the following:

Aleksandra Šajnović, Ksenija Stojanović, Vladimir Simić and Branimir Jovančićević (2012). Geochemical and Sedimentation History of Neogene Lacustrine Sediments from the Valjevo-Mionica Basin (Serbia), Geochemistry - Earth's System Processes, Dr. Dionisios Panagiotaras (Ed.), ISBN: 978-953-51-0586-2, InTech, Available from: http://www.intechopen.com/books/geochemistry-earth-s-systemprocesses/geochemical-and-sedimentation-history-of-neogene-lacustrine-sediments-from-the-valjevo-mionicabasin

\section{INTECH}

open science | open minds

\section{InTech Europe}

University Campus STeP Ri

Slavka Krautzeka 83/A

51000 Rijeka, Croatia

Phone: +385 (51) 770447

Fax: +385 (51) 686166

www.intechopen.com

\section{InTech China}

Unit 405, Office Block, Hotel Equatorial Shanghai

No.65, Yan An Road (West), Shanghai, 200040, China

中国上海市延安西路 65 号上海国际贵都大饭店办公楼 405 单元

Phone: +86-21-62489820

Fax: $+86-21-62489821$ 
(C) 2012 The Author(s). Licensee IntechOpen. This is an open access article distributed under the terms of the Creative Commons Attribution 3.0 License, which permits unrestricted use, distribution, and reproduction in any medium, provided the original work is properly cited. 